\title{
Drug Overdose in a Retrospective Cohort with Non-Cancer Pain Treated with Opioids, Antidepressants, and/or Sedative-Hypnotics: Interactions with Mental Health Disorders
}

\author{
Barbara J. Turner, M.D., M.S.Ed. ${ }^{1,2,3}$ and Yuanyuan Liang, Ph.D. ${ }^{2,3,4}$ \\ 'Division of General Internal Medicine, Department of Medicine, University of Texas Health Science Center San Antonio (UTHSCSA), San Antonio, TX, \\ USA; ${ }^{2}$ Center for Research to Advance Community Health (ReACH), University of Texas Health Science Center San Antonio, San Antonio, TX, USA; \\ ${ }^{3}$ School of Public Health, University of Texas Health Science Center at Houston, Houston, TX, USA; ${ }^{4}$ Department of Epidemiology and Biostatistics, \\ University of Texas Health Science Center San Antonio, San Antonio, TX, USA.
}

BACKGROUND: Opioid analgesics and other psychoactive drugs may pose an even greater risk for drug overdose in persons with mental health disorders.

OBJECTIVE: The purpose of this study was to examine interactions of filled prescriptions for opioids, benzodiazepines, antidepressants, and zolpidem with mental health disorders in regard to drug overdose.

DESIGN: The study was a retrospective cohort review. SUBJECTS: Subjects were national HMO beneficiaries aged 18-64 years, enrolled at least 1 year $(01 / 2009$ to 07/2012), who filled at least two prescriptions for Schedule II or III opioids for non-cancer pain.

MAIN MEASURES: The outcome was the first inpatient or outpatient drug overdose after the first filled opioid prescription. Predictors were calculated in 6-month intervals and exactly 6 months before a drug overdose: opioid use (mean daily morphine-equivalent dose), benzodiazepine use (days' supply), antidepressant use (days' supply), zolpidem use (days' supply), mental health disorders (depression, anxiety/PTSD, psychosis), pain-related conditions, and substance use disorders (alcohol, other drug). KEY RESULTS: A total of 1,385 (0.67\%) subjects experienced a drug overdose (incidence rate 421/100,000 person-years). The adjusted odds ratios (AOR) for overdose among all subjects rose monotonically with daily opioid dose, but highest (AOR=7.06) for persons with depression and a high opioid dose ( $\geq 100 \mathrm{mg}$ ) versus no depression or opioid use. Longer-term antidepressants (91-180 days) were protective for persons with depression, with $20 \%$ lower AORs for overdose versus short-term (1-30 days) or none. For persons without depression, the AORs of overdose were increased for antidepressant use, but greatest (AOR=1.98) for short-term use versus none. The AORs of overdose increased with the duration of benzodiazepine therapy among all subjects, with over 2.5-fold higher AORs for 91-180 days versus none.

CONCLUSIONS: Opioids and longer-duration benzodiazepines were associated with drug overdose among all subjects, but opioid risk was greatest for persons with depression. Antidepressant use $>90$ days reduced the odds of overdose for persons with depression, but all antidepressant use increased the risk for persons without depression.

Received July 3, 2014

Accepted January 14, 2015

Published online February 4, 2015
KEY WORDS: opioid analgesics; overdose; psychotherapeutic drugs.

J Gen Intern Med 30(8):1081-96

DOI: $10.1007 / \mathrm{s} 11606-015-3199-4$

(C) Society of General Internal Medicine 2015

\section{INTRODUCTION}

Between 1999 and 2009, U. S. rates of mortality from accidental pharmaceutical drug overdose rose over fourfold for opioid analgesics and threefold for sedative-hypnotics. ${ }^{1}$ Of the more than 22,000 unintentional pharmaceutical overdose deaths nationally in 2010, three-quarters involved opioid analgesics, while benzodiazepines were identified in one-quarter and antidepressants in nearly $20 \%{ }^{2}$ Concurrent use of these drugs appears to carry an even higher risk. The combination of prescribed opioids and benzodiazepines is the most common cause of polysubstance overdose deaths nationally. ${ }^{1}$ Persons with mental health disorders are more likely to be treated for chronic pain with high-dose opioid therapy that has also been associated with more coprescribed sedative-hypnotic therapy. ${ }^{3}$ However, we are unaware of studies examining the risk of drug overdose for complex interrelationships of multiple drugs commonly used by persons with chronic pain and comorbid mental health disorders.

We hypothesized that patients with mental health disorders who take opioids and other psychotherapeutic drugs would have a significantly greater risk for overdose than those who do not. To examine these hypotheses, we analyzed a longitudinal database from a national health maintenance organization (HMO) of persons with non-cancer pain who filled multiple prescriptions for opioid analgesics. This study offers insights into the risks and potential benefits of opioids, benzodiazepines, antidepressants, and/or zolpidem for persons with mental health disorders.

\section{METHODS}

\section{Study Setting}

The study utilized patient data from the Aetna Health Maintenance Program that provides comprehensive fullservice care to approximately 2.1 million persons nationally. 
Study data were obtained from enrollment files and claims for services and prescriptions. The study was approved by the Institutional Review Board of the University of Texas Health Science Center at San Antonio.

Study Subjects. The study cohort included persons aged 18 to 64 years with non-cancer pain who filled at least two Schedule II or III prescriptions for non-injectable opioid analgesics from January 2009 through July 2012. Eligible subjects were continuously enrolled at least 12 months in the Aetna plan and had claims for service utilization at least 6 months before the first drug overdose event. The cohort derivation revealed that the most frequent exclusions were due to incomplete opioid prescription data, missing diagnostic data, or a non-basal cell cancer diagnosis (Fig. 1).

Study subjects' medications and clinical conditions were examined for each 6-month interval after the first filled opioid prescription, up to a maximum of seven intervals. Incomplete intervals were excluded. Examples of 6-month interval data for three sample patients are shown in Fig. 2. Subject A had no overdose event; therefore, time-varying covariates were examined for each complete 6 month-interval after the first filled opioid prescription until the subject left the plan or the study time frame ended. Subject B had an overdose within the first 6 -month interval. To examine a full 6 months before that event, covariates were based on data from services and medications received before and after the first opioid prescription. For subject $\mathrm{C}$, the overdose occurred in the third 6-month

Schedule II or II opioid analgesic prescription filled from
$01 / 2009$ to $07 / 2012$
Exclusions:
Enrolled < 12 months
Missing demographic data
Age<18 or $>64$ yr
Incomplete data on opioid analgesic prescriptions
(N=20,394)
<2 Schedule II or III opioid analgesic prescriptions
Incomplete prescriber data

Figure 1 Derivation of study cohort of persons filling at least two prescriptions for Schedule II or III opioid analgesics. interval; therefore, time-varying covariates were calculated for 6-month intervals without an event and from the 6 months before the overdose event. Subjects were censored after the first overdose.

Outcome Variable. The study outcome was drug overdose diagnosed from an inpatient or outpatient clinical encounter following the first filled opioid prescription (drug overdose ICD-9-CM codes in Appendix 1). For each subject, this timevarying outcome was measured in each 6-month interval after the first filled opioid prescription until last enrollment or end of the study time frame. For subjects with multiple overdose events in a given 6-month interval, only the first was considered.

Classification of Morphine-Equivalent Dose. Using an approach previously reported by our group, ${ }^{4}$ a morphineequivalent dose (MED) for each Schedule II or III opioid prescription (non-injectable formulations) was calculated from the number of pills dispensed multiplied by strength (in milligrams), then multiplied by a morphine-equivalent conversion factor derived from several sources, including published data, 5,6 conversion tables from Internet sources, and drug information resources (Table 2 in Appendix 2). ${ }^{7,8}$ A clinical pharmacist assisted with calculating conversions. We capped the daily dose based on the maximum recommended for that drug.

The total MED was computed by summing the MEDs for all opioid prescriptions within a given 6-month interval. The mean daily MED in a 6-month interval was calculated by dividing the total MED by days' supply for all prescriptions in that interval, excluding overlapping days. We examined five categories for the mean daily MED (i.e., $0,1-$ $19,20-49,50-99$, and $\geq 100 \mathrm{mg}$ ), similar to other studies. ${ }^{9,10}$ For the first overdose, the mean daily MED was based on data from exactly 6 months before that event (Fig. 2).

Classification of Psychoactive Medications. For each 6month interval, we summed the days' supply for antidepressants (i.e., SSRIs, SNRIs, and tricyclics), benzodiazepines, and zolpidem. The duration of each drug class or drug was categorized for analysis as follows: $0,1-30,31-90$, and 91180 days. Similar to opioid therapy, these time-varying covariates were measured for each 6-month interval, as well as the 6 months before the first overdose event if applicable.

Demographic and Clinical Variables. Study subject demographic data included age as of July 2012, sex, and U.S. region of residence from among four categories as defined by the Centers for Disease Control and Prevention. Time-varying indicators for pain-related conditions were created for each 6-month interval using diagnosis codes for outpatient and hospital encounters, and included the following: back pain, large joint arthritis/other musculoskeletal disorders, neuropathic pain, unspecified chronic pain, and 


\begin{tabular}{|c|c|c|c|c|c|c|c|}
\hline Subject & \multicolumn{7}{|c|}{ 6-Month Interval after First Opioid Prescription $\dagger$} \\
\hline & 1 & 2 & 3 & 4 & 5 & 6 & 7 \\
\hline A & & & & & & & \\
\hline B & & & & & & & \\
\hline $\mathrm{C}$ & & & & & & & \\
\hline
\end{tabular}

Figure 2 Calculation of covariates for persons with an overdose event* and comparison group.* Dark arrow shows the date of the overdose event. Persons with an overdose event are censored after the first overdose event. $\dagger$ Date of first opioid prescription indicated by dark line. $A$ If no overdose occurred, up to seven 6-month intervals would be observed. Covariates were examined in each observed 6-month interval. $B$ Overdose occurred within 6 months of the first opioid prescription, covariates determined from 6 months prior to the overdose date. Comparison group: persons with no event in the first interval (such as $A$ and $C$ in interval 1). $C$ Overdose occurred in third 6-month interval, covariates examined from prior 6 months spanning second and third 6-month intervals. Comparison group: persons with no event in the third interval (such as $A$ in interval 3 ).

chronic headache (ICD-9-CM codes). Time-varying indicators were also created for mental health/substance use disorders, including anxiety or post-traumatic stress disorder (PTSD), depression, psychosis, drug abuse, and alcohol abuse. Anxiety and PTSD were combined, as the latter was uncommon $(<1 \%)$, and these conditions often overlap. Because psychiatric conditions and substance use disorders are usually not transient, once a diagnosis occurred within a 6-month interval, it was considered to persist subsequently. The ICD9-CM codes used to identify clinical conditions are available upon request.

Analyses. Study cohort characteristics were summarized using descriptive statistics. Differences in characteristics of patients with and without a drug overdose event were examined using the chi-square test for categorical variables and the two-sample $\mathrm{t}$ test with an unequal variance assumption for continuous variables. Patterns of treatment with drugs of interest were examined descriptively for each 6-month interval. Using repeated-measures logistic regression with the generalized estimating equations method under an unstructured correlation matrix, we examined the effects of daily opioid dose and duration of filled prescriptions for psychoactive drugs on the odds of overdose, adjusting for time-fixed covariates (i.e., age, sex, and region) as well as time-varying covariates (i.e., chronic pain conditions, mental health, and substance use disorders). Clinical judgment guided a backward model selection procedure. We started with a full model including demographics, clinical conditions, substance use disorders (i.e., drug or alcohol), and medications, as well as all possible interactions of daily opioid dose with each of the three psychoactive drug groups (i.e., benzodiazepines, antidepressants, and zolpidem), and interactions of each of these drugs with mental health conditions (i.e., anxiety/PTSD, depression, and psychotic disorder). The final model included clinically important and/or statistically significant factors. We conducted a post hoc descriptive analysis of combination therapy in each 6-month interval separately for persons diagnosed with depression or
anxiety/PTSD. All statistical tests were performed with a twosided significance level of 0.05 and analyses conducted using SAS software (Version 9.3).

\section{RESULTS}

The study cohort comprised over 206,000 subjects; $57 \%$ were women, and the average age was 44 years (Table 1). Nearly half of the cohort resided in southern states, reflecting the distribution of the HMO plan. The most common non-cancer pain-related conditions were musculoskeletal, including large joint arthritis/other musculoskeletal disorders, and back pain-related conditions. With regard to mental health conditions, anxiety/PTSD and depression occurred in 15 and $13 \%$ of the cohort, respectively, while psychosis and alcohol and other substance use disorders were each diagnosed in less than $3 \%$.

Over the course of 3.5 years, 1,385 of 206,869 $(0.67 \%)$ subjects were diagnosed with a drug overdose (Table 1). With the exception of region of residence, persons with an overdose event differed significantly in all observed patient characteristics. Persons who experienced a drug overdose were more likely to be women and of a younger age than those that did not. The greatest clinical differences appeared in patients diagnosed with back pain, chronic pain (unspecified), mental health conditions, and substance use disorders.

Across all 658,280 6-month intervals observed for the cohort, the incidence rate for drug overdose was 421 per 100,000 person-years. The proportion of subjects with a drug overdose was highest $(0.06 \%)$ in the first 6-month interval, declining in subsequent intervals from 0.04 to $0.01 \%$. After the first interval, during which all subjects filled at least one opioid prescription, the proportion receiving opioids subsequently stabilized at 42 to $50 \%$, with the exception of the last interval, when it 
Table 1 Study Cohort Characteristics

\begin{tabular}{|c|c|c|c|}
\hline \multirow[t]{2}{*}{ Characteristics } & \multicolumn{2}{|c|}{ Any drug overdose event ${ }^{*}$} & \multirow{2}{*}{$\begin{array}{l}\text { Total } \\
(N=206,869)\end{array}$} \\
\hline & No $(N=\mathbf{2 0 5}, \mathbf{4 8 4})$ & Yes $(N=1385)$ & \\
\hline \multicolumn{4}{|l|}{ Demographics } \\
\hline Women, n $(\%)$ & $116,585(56.7)$ & $887(64.0)$ & $117,472(56.8)$ \\
\hline Age, mean (SD) & $44.1(12.0)$ & $42.5(12.4)$ & $44.1(12.0)$ \\
\hline \multicolumn{4}{|l|}{ U.S. Region, n (\%) } \\
\hline Midwest & $11,950(5.8)$ & $78(5.6)$ & $12,028(5.8)$ \\
\hline Northeast & $60,146(29.3)$ & $421(30.4)$ & $60,567(29.3)$ \\
\hline South & $96,413(46.9)$ & $659(47.6)$ & $97,072(46.9)$ \\
\hline West & $36,975(18.0)$ & $227(16.4)$ & $37,202(18.0)$ \\
\hline \multicolumn{4}{|l|}{ Clinical conditions ${ }^{\dagger}, \mathrm{n}(\%)$} \\
\hline \multicolumn{4}{|l|}{ Non-cancer pain conditions } \\
\hline Large joint arthritis, other musculoskeletal ${ }^{\ddagger}$ & $101,577(49.4)$ & $739(53.4)$ & $102,316(49.5)$ \\
\hline Back pain & $79,801(38.8)$ & $722(52.1)$ & $80,523(38.9)$ \\
\hline Neuropathy & $1762(0.9)$ & $26(1.9)$ & $1788(0.9)$ \\
\hline Chronic pain (unspecified) & $13,874(6.8)$ & $337(24.3)$ & $14,211(6.9)$ \\
\hline Headache & $14,460(7.0)$ & $175(12.6)$ & $14,635(7.1)$ \\
\hline \multicolumn{4}{|l|}{ Mental health and substance use disorders } \\
\hline Anxiety or post-traumatic stress disorder & $30,308(14.8)$ & $579(41.8)$ & $30,887(14.9)$ \\
\hline Depression & $25,466(12.4)$ & $757(54.7)$ & $26,223(12.7)$ \\
\hline Psychosis & $5268(2.6)$ & $335(24.2)$ & $5603(2.7)$ \\
\hline Alcohol abuse & $4283(2.1)$ & $354(25.6)$ & $4637(2.2)$ \\
\hline Other substance abuse & $4044(2.0)$ & $376(27.2)$ & $4420(2.1)$ \\
\hline
\end{tabular}

${ }^{*} P$ value for comparison of all variables was $<0.001$ except for region (0.43)

${ }^{+}$Clinical conditions diagnosed at any point in study time frame. ICD-9-CM codes available from authors

* Arthritis, arthralgia, fracture, sprains

was approximately $60 \%$. In the first interval, over onethird of subjects received higher-daily-dose opioids ( $\geq 50 \mathrm{mg}$ ), which then declined to about $16 \%$, except for the last interval, when nearly $30 \%$ received higherdose opioids.

With regard to psychoactive medications, 19 to $24 \%$ of the cohort filled one or more antidepressant prescriptions in each 6-month interval, with 11 to $16 \%$ filling over 90 days' supply in a given interval. Fifteen to twenty-five percent of the cohort filled at least one benzodiazepine prescription, and 7 to $13 \%$ received more than 90 days' supply. At least one zolpidem prescription was filled by 8 to $12 \%$ of the cohort, with 4 to $7 \%$ filling more than 90 days' supply.

In the fully adjusted model predicting drug overdose, the following significant interactions were observed: opioid therapy with depression $(\operatorname{chi}(4)=36.53, p<0.001)$; antidepressant therapy with depression (chi( 3$)=20.20, p<0.001)$; benzodiazepine therapy with anxiety/PTSD ( $\operatorname{chi}(3)=10.36, p=0.016)$ and zolpidem therapy with anxiety/PTSD diagnosis $(\operatorname{chi}(3)=8.79$, $p=0.03$ ) (Fig. 3; full model-fitting results in Appendix 3). In the interaction between opioid therapy and depression (Fig. 3a), the adjusted odds of overdose were significantly higher for persons with depression than those without this diagnosis, regardless of opioid dose (all $p<0.001$ ). The adjusted odds of drug overdose were 7.06 (95\% CI: 5.30 to 9.42) for the combined effect of depression and very high opioid dose $(\geq 100 \mathrm{mg}$ ) versus no depression or opioid use. Among persons without depression, drug overdose was associated with increasing opioid dose (chi2(4)=161.4, $p<0.001)$, but the risk rose gradually with all but a very high daily dose, for which the adjusted odds were 4.34 (95\% CI: 3.37 to 5.57) versus no opioids. Among persons with depression, an increasing opioid dose monotonically increased the likelihood of drug overdose $(\operatorname{chi} 2(4)=24.20, p<0.001)$, with adjusted odds of $1.78(95 \%$ CI: 1.39 to 2.29 ) for a very high opioid dose versus no opioids.

An interaction between antidepressant therapy and depression (Fig. 3b) showed that regardless of antidepressant therapy, the risk of drug overdose was significantly greater for persons diagnosed with depression than for those who were not (all $p<0.001$ ). For persons with depression, long-term antidepressant therapy (91-180 days) was associated with overdose events $(\operatorname{chi} 2(3)=8.49, p=0.037)$, but this association was protective, with an adjusted odds ratio of 0.79 (95\% CI: 0.66 to 0.95$)$ versus none. On the other hand, shorter-term therapy ( $\leq 90$ days) had no benefit ( $p=0.72$ for $1-30$ days; $p=0.133$ for $31-90$ days). For persons without a diagnosis of depression, antidepressant therapy increased the likelihood of overdose $(\operatorname{chi} 2(3)=28.10, p<0.001)$; this effect was greatest for short-term (1-30 days) antidepressant use, with adjusted odds of 1.98 (95\% CI: 1.48 to 2.65 ), declining to 1.33 (95\% CI: 1.05 to $1.68, p=0.018$ ) for long-term antidepressants (91180 days) versus none.

Among all subjects, the likelihood of overdose was similarly increased by benzodiazepine therapy, regardless of duration (all $p>0.06$ ) (Fig. 3c). An interaction showed that duration of benzodiazepine therapy among persons with anxiety/PTSD had a non-monotonic association with drug overdose, but the association was monotonic among persons without anxiety/ PTSD. The adjusted odds for drug overdose was highest $[\mathrm{OR}=2.85$ (95\% CI: 2.34 to 3.48)] for persons without anxiety/PTSD who received long-term (91-180 days) benzodiazepine therapy versus none.

Zolpidem use similarly increased the odds of overdose for persons with or without anxiety/PTSD (all $p>0.10$ ), except for 
A Interaction between Opioids and Depression

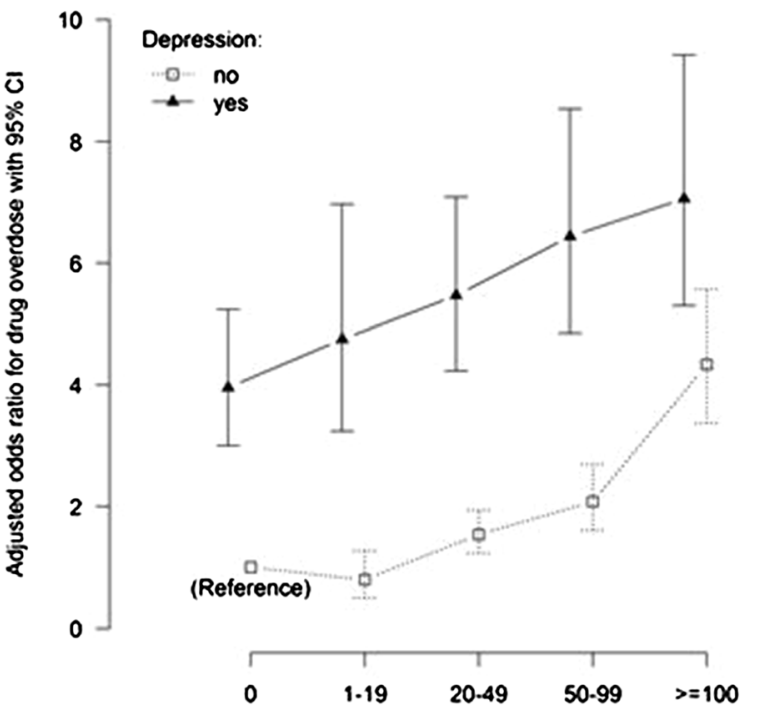

Opioid analgesic dose (average daily dose per 6 month interval)

\section{Interaction between Benzodiazepines and Anxiety/PTSD}

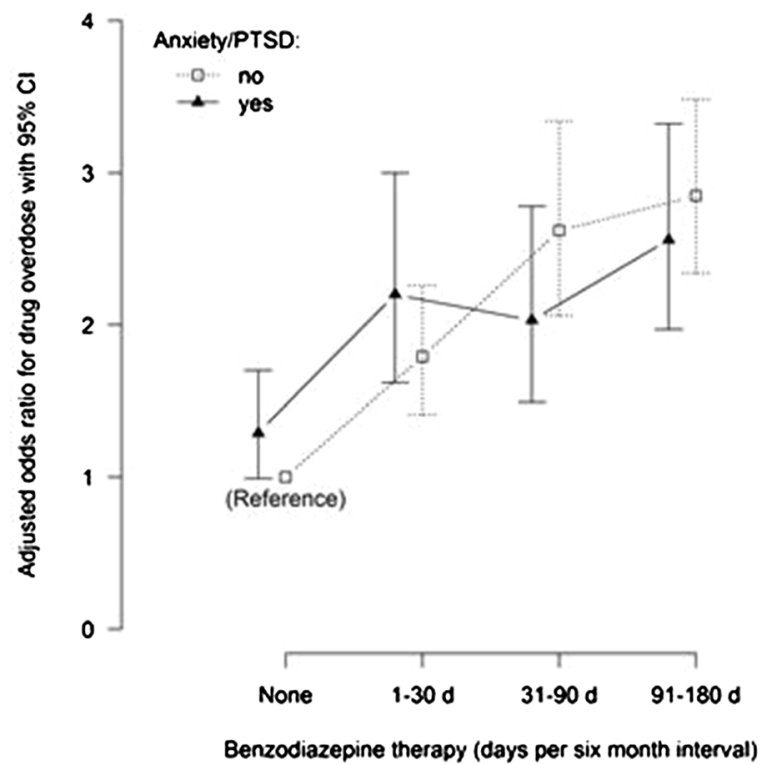

B Interaction between Antidepressants and Depression

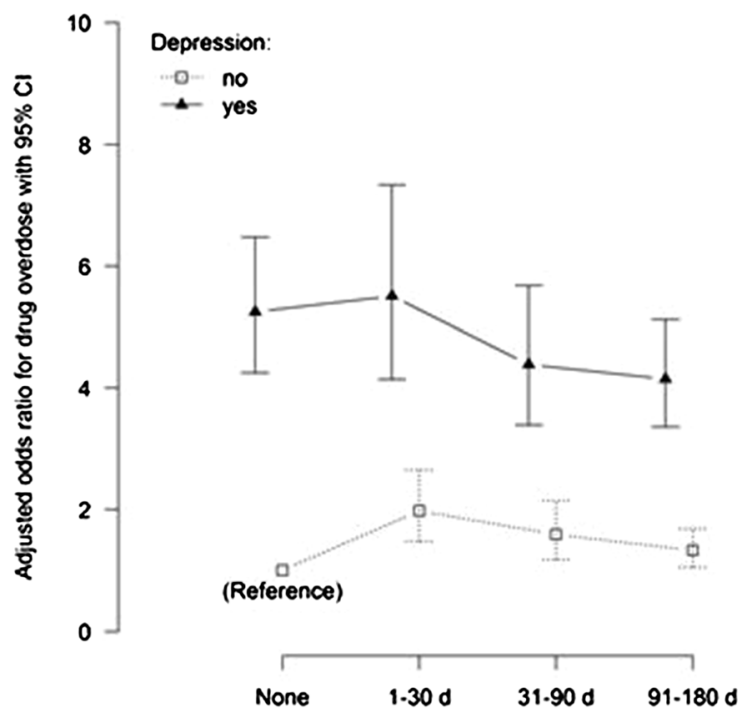

Antidepressant therapy (days per 6 month interval)

\section{Interaction between Zolpidem and Anxiety/PTSD}

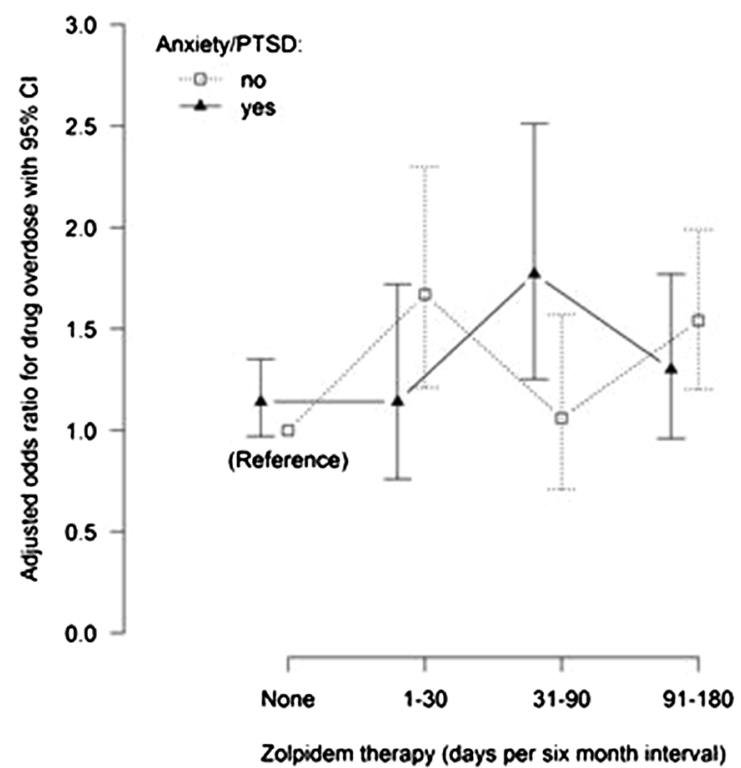

Figure 3 Adjusted odds ratios for drug overdose associated with significant interactions of opioid analgesics and selected psychotherapeutic drugs with mental health conditions. Other variables in the model include: daily morphine-equivalent dose category, time interval, age, gender, region, five chronic non-cancer pain conditions, anxiety/PTSD, depression, psychotic disorder, alcohol abuse, drug abuse, antidepressant therapy, benzodiazepine therapy, and zolpidem per 6-month interval (medications analyzed in four levels: none, 1-30 days, 31-90 days, 91-180 days).

31-90 days ( $p=0.05)$. Among persons with anxiety/PTSD, duration of zolpidem use was not associated with drug overdose events (chi2(3) $=6.52, p=0.089$ ), but among those without anxiety/PTSD, the association was significant $(\operatorname{chi} 2(3)=18.92$, $p<0.0001)$. Among persons without anxiety/PTSD, the adjusted odds of overdose were 1.67 (95\% CI: 1.21 to 2.30) for short-term therapy (1-30 days) versus none, and 1.54 (95\% CI: 1.20 to 1.99$)$ for long-term therapy (91-180 days) versus none. However, the odds of overdose were highest for persons with anxiety/PTSD and 31-90 days of zolpidem therapy
$(\mathrm{OR}=1.77,95 \% \mathrm{CI}: 1.25$ to 2.51$)$ versus no anxiety/PTSD and no zolpidem.

A post hoc analysis revealed that among persons diagnosed with depression, treatment with multiple medications was most likely to have occurred in the first 6-month interval, when all subjects filled opioid prescriptions and $69 \%$ also received antidepressants, $45 \%$ received benzodiazepines, and $20 \%$ received zolpidem (Table 5 in Appendix 4). Prescriptions for all four classes of drugs were filled by 5 to $10 \%$ of patients with depression, depending on the 6-month interval. Among 
patients with anxiety/PTSD, over half also filled prescriptions for antidepressants or benzodiazepines in the first 6 month-interval, and about $25 \%$ continued both opioids and antidepressants in subsequent intervals, while about $30 \%$ continued both opioids and benzodiazepines.

\section{DISCUSSION}

Among over 200,000 HMO beneficiaries with noncancer pain who filled multiple prescriptions for Schedule II or III opioids, complex interactions with regard to risk of drug overdose appeared between mental health disorders and treatment with opioids or other psychotherapeutic drugs. The adjusted odds of drug overdose in a 6-month interval for high daily morphine-equivalent dose of $\geq 100 \mathrm{mg}$ increased sevenfold for persons with depression and fourfold for persons without depression. These data are consistent with studies reporting up to a ninefold greater risk of opioid overdose for high-dose opioid therapy $(\geq 100 \mathrm{mg}){ }^{10}$ although our analyses more clearly distinguish the risk for persons with depression.

A novel finding in this study among persons diagnosed with depression was a significant protective effect with regard to drug overdose for longer-term (>90 days) antidepressant therapy compared to no antidepressant use. Depression is highly prevalent in persons with chronic pain, ranging from 18 to $56 \%$ in a systematic review. ${ }^{11}$ A mood disorder may precede or often follows the development of chronic pain and is associated with greater pain severity. ${ }^{12}$ Long-term antidepressant therapy can offer dual benefits of improving mood and, as reported in a recent systematic review, improved pain-related outcomes for diverse types of painful conditions. ${ }^{13}$

On the other hand, among persons without depression, antidepressant therapy was associated with significantly greater odds of drug overdose, which was greatest for short-term (1-30 days) therapy. This is unlikely due to suicide attempts after initiating antidepressants, which has primarily been a concern for children and adolescents, ${ }^{14}$ or to poisoning by these drugs, as it is relatively rare. ${ }^{15}$ Several studies have reported no benefit for short-term antidepressant therapy in the treatment of depression, but less is known about the effects on pain. ${ }^{16,17}$ Short-term antidepressant therapy may be an indicator for non-adherence $^{16}$ to this medication and increased reliance on riskier medications for pain management. Alternatively, in an analysis of root causes of opioid overdose deaths, Webster and colleagues suggested that antidepressant use could pose risks due to central nervous system depressant effects, and recommended structured care for persons with mental health disorders who are treated with opioids for pain. ${ }^{18}$ Unfortunately, psychiatric care is lacking in the management of many chronic pain patients. ${ }^{19}$
Calcaterra and colleagues reported that opioids plus benzodiazepines were the most common cause of polysubstance overdose deaths in a national study from 1999 to 2009, and increased the risk of drug overdose associated with opioids. ${ }^{1}$ In our cohort, benzodiazepines significantly increased the risk of overdose but did not disproportionately affect persons with mental health disorders. However, we did find that the odds of overdose progressively rose with longer duration of benzodiazepine therapy. In our national HMO cohort, $45 \%$ of depressed patients were receiving concurrent opioids and benzodiazepines at any one time, and this dangerous combination additively increased the likelihood of overdose. Depending on duration of use, zolpidem increased the odds of overdose by as much as $77 \%$, and was received by 10 to $20 \%$ of patients with opioids. These data add to the body evidence of risks for zolpidem use along with other frequently misused drugs such as opioids. ${ }^{20}$

This study has several limitations to acknowledge. First, we relied on coded diagnoses to identify mental health disorders that have limited sensitivity, although this misclassification should attenuate our findings, because persons with depression would be included among those without. We also relied on coded diagnoses to identify drug overdose events that miss overdoses occurring out of network or resulting in outpatient death. However, the rate of drug overdose events in this cohort $(421 / 100,000$ person-years) in inpatient and outpatient health care settings was predictably higher than the rate of $238.1 / 100,000$ person-years for drug overdose from an analysis of only emergency room visits in North Carolina in 2011. ${ }^{21}$ Second, we assumed that patients were taking drugs after they filled prescriptions, but non-adherence for opioids in particular is a major concern. ${ }^{22,23}$ In addition, total and average daily opioid dose were computed using days' supply data that may not be reliable. Third, we examined patients' medications and overdose events in 6-month intervals in order to establish a tractable but reasonably long time frame to examine receipt of drugs and this outcome. By design, our analysis only considers prescriptions filled before the overdose event. Reassuringly, our observed associations between opioid use and overdose are similar to those from longitudinal studies of drugs prescribed before an opioid-related overdose death. ${ }^{24}$ Fourth, drug overdoses in this cohort may have been due to illicit drug use. According to the CDC, however, opioid painkillers have been involved in the majority of unintentional drug overdose deaths nationally since $2003 .{ }^{25}$ Fifth, we were unable to distinguish unintentional overdose from suicide attempts. Sixth, although we adjusted for alcohol and other drug abuse disorders, these conditions likely further complicate observed interactions of opioids and other psychotropic medications with mental health disorders.

This study has several notable strengths. We examined all drug overdose events, instead of only deaths, which represent only a small fraction of these events. 
We used data for filled prescriptions instead of prescriptions from an electronic medical record that may or may not have been filled. Our study also has several implications for clinical practice. Among persons with depression, opioid use had a dose-response association with increased odds of drug overdose, and thus dose minimization is essential. Among persons without depression, the odds of overdose rose rapidly for a daily opioid dose of $100 \mathrm{mg}$ or higher. These data reinforce recommendations to use non-pharmacologic pain management approaches such as cognitive behavioral therapy as a means to limit opioid use. ${ }^{26}$ We also found that duration of benzodiazepine use was linearly associated with greater overdose risk, but even short-term treatment was positively associated with overdose. Concurrent use of these drugs is common, and represents an important risk. Although the effect of zolpidem was lower, it nonetheless additively increased the risk of overdose. With regard to risk mitigation, our study found a significant protective effect with antidepressant therapy for longer than 90 days among persons diagnosed with depression. Unfortunately, antidepressants appeared to increase the risk of overdose for persons without depression. Overall, these data reinforce the complexities of medication management for chronic pain and support expert recommendations to employ non-drug approaches to pain control while minimizing the risks associated with these drugs. ${ }^{27}$

ACKNOWLEDGEMENTS AND CONFLICT OF INTEREST: The work on this project was supported by an intramural grant from the National Center for Research Resources and the National Center for Advancing Translational Sciences, National Institutes of Health, through Grant 1UL TR001120. The content is solely the responsibility of the authors and does not necessarily represent the official views of the NIH.

Corresponding Author: Barbara J. Turner, M.D., M.S.Ed.; Division of General Internal Medicine, Department of Medicine, University of Texas Health Science Center San Antonio (UTHSCSA), 7411 John Smith Rd. Suite 1050, San Antonio, TX 78229, USA (e-mail: turner@uthscsa.edu).

\section{REFERENCES}

1. Calcaterra S, Glanz J, Binswanger IA. National trends in pharmaceutical opioid related overdose deaths compared to other substance related overdose deaths: 1999-2009. Drug Alcohol Depend. 2013;131(3):263-70.

2. Jones CM, Mack KA, Paulozzi LJ. Pharmaceutical overdose deaths, United States, 2010. JAMA. 2013;309(7):657-9.

3. Kobus AM, Smith DH, Morasco BJ, et al. Correlates of higher-dose opioid medication use for low back pain in primary care. J Pain. 2012;13(11):1131-8.

4. Liang Y, Turner BJ. Assessing risk for drug overdose in a national cohort: role for both daily and total opioid dose? J Pain. 2014. doi:10.1016/j.jpain 2014.11.007.

5. Foley KM. The treatment of cancer pain. N Engl J Med. 1985;313(2):84-95.

6. Vissers KC, Besse K, Hans G, Devulder J, Morlion B. Opioid rotation in the management of chronic pain: where is the evidence? Pain Pract. 2010;10(2):85-93.

7. Agency Medical Director's Group. Web-Based Opioid Dose Calculator. Available at http://agencymeddirectors.wa.gov/mobile.html. Accessed April 7, 2014
8. Hallenbeck JL. Palliative Care Perspectives. Oxford: Oxford University Press; 2003:36-74.

9. Bohnert AS, Valenstein M, Bair MJ, et al. Association between opioid prescribing patters and opioid overdose-related deaths. JAMA. 2011;305(13): 1315-21.

10. Dunn KM, Saunders KW, Rutter CM, et al. Opioid prescriptions for chronic pain and overdose: a cohort study. Ann Intern Med. 2010;152(2):85-92.

11. Bair MJ, Robinson RL, Katon W, Kroenke K. Depression and pain comorbidity: a literature review. Arch Intern Med. 2003;163(20):2433-45.

12. Gerrits MM, van Oppen P, van Marwijk HW, Penninx BW, van der Horst HE. Pain and the onset of depressive and anxiety disorders. Pain. 2014;155(1):53-9.

13. Mercier A, Auger-Aubin I, Lebeau JP, et al. Evidence of prescription of antidepressants for non-psychiatric conditions in primary care: an analysis of guidelines and systematic reviews. BMC Fam Pract. 2013;4:14-55.

14. Bridge JA, Iyengar S, Salary CB, Barbe RP, Birmaher B, Pincus HA, Ren L, Brent DA. Clinical response and risk for reported suicidal ideation and suicide attempts in pediatric antidepressant treatment: a meta-analysis of randomized controlled trials. JAMA. 2007;297(15):1683-96.

15. McKenzie MS, McFarland BH. Trends in antidepressant overdoses. Pharmacoepidemiol Drug Saf. 2007;16(5):513-23.

16. Stewart JA, Deliyannides DA, Hellerstein DJ, McGrath PJ, Stewart JW. Can people with nonsevere major depression benefit from antidepressant medication? J Clin Psychiatry. 2012;73:518-25.

17. Serna MC, Cruz I, Real J, Gascó E, Galván L. Duration and adherence of antidepressant treatment (2003 to 2007) based on prescription database. Eur Psychiatry. 2010;25:206-13.

18. Webster LR, Cochella S, Dasgupta N, Fakata KL, Fine PG, Fishman SM, Grey T, Johnson EM, Lee LK, Passik SD, Peppin J, Porucznik CA, Ray A, Schnoll SH, Stieg RL, Wakeland W. An analysis of the root causes for opioid-related overdose deaths in the United States. Pain Med. 2011;12(Suppl 2):S26-35.

19. Howe CQ, Sullivan MD. The missing ' $\mathrm{P}$ ' in pain management: how the current opioid epidemic highlights the need for psychiatric services in chronic pain care. Gen Hosp Psychiatry. 2014;36(1):99-104.

20. Zosel A, Osterberg EC, Mycyk MB. Zolpidem misuse with other medications or alcohol frequently results in intensive care unit admission. Am J Ther. 2011;18(4):305-8.

21. Harmon KJ, Proescholdbell S, Marshall S, Waller A. Utilization of emergency department data for drug overdose surveillance in North Carolina. Online J Public Health Inform. 2014;6(1):e174.

22. Matteliano D, Chang YP. Describing prescription opioid adherence among individuals with chronic pain using urine drug testing. Pain Manag Nurs. 2014 Jun.

23. Anastassopoulos KP, Chow W, Tapia CI, Baik R, Moskowitz B, Kim MS. Reported side effects, bother, satisfaction, and adherence in patients taking hydrocodone for non-cancer pain. J Opioid Manag. 2013:9(2):97-109.

24. Bohnert AS, Ilgen MA, Ignacio RV, McCarthy JF, Valenstein M, Blow FC. Risk of death from accidental overdose associated with psychiatric and substance use disorders. Am J Psychiatry. 2012;169(1):64-70.

25. Centers for Disease Control and Prevention (CDC). CDC grand rounds: prescription drug overdoses - a U.S. epidemic. MMWR Morb Mortal Wkly Rep. 2012;61(1):10-3

26. Windmill J, Fisher E, Eccleston C, Derry S, Stannard C, Knaggs R, Moore RA. Interventions for the reduction of prescribed opioid use in chronic non-cancer pain. Cochrane Database Syst Rev. 2013;9, CD010323.

27. Washington State Agency Medical Directors' Group. Interagency Guideline on Opioid Dosing for Chronic Non-cancer Pain: An Educational Aid to Improve Care and Safety with Opioid Treatment. Olympia (WA): Washington State Department of Labor and Industries; 2010 (http://www.guideline.gov/content.aspx?id=23792)

\section{APPENDIX 1. ICD-9-CM CODE FOR DIAGNOSIS OF DRUG OVERDOSE}

ICD-9-CM code, 965.0, 965.00, 965.02, 965.09, 965.1, 965.4, 965.61, 965.69, 965.8, 965.9, 967.6, 967.8, 967.9, 969.4, 977.9, E850.1-E850.6, E850.8, E850.9, E852.8, E852.9, $\mathrm{E} 853.2$, E950.0 or E950.2. 
APPENDIX 2

Table 2 Morphine Conversion Factors

\begin{tabular}{|c|c|c|c|c|c|c|c|}
\hline 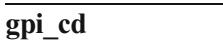 & drug_nm & gpi_nm & short_act & max_daily & morph_eqv_fctr & drg_strnth_mg & $\overline{\text { adj_dose }}$ \\
\hline 65991002052020 & $\begin{array}{l}\text { APAP/CODEINE } \\
\text { SOL } 120-12 / 5\end{array}$ & $\begin{array}{l}\text { Acetaminophen } \\
\text { w/ Codeine Soln } \\
120-12 \mathrm{MG} / 5 \mathrm{ML}\end{array}$ & 1 & 150 & 0.15 & 2.4 & 0.36 \\
\hline 65991002051805 & $\begin{array}{l}\text { CAPITAL/COD } \\
\text { SUS } 120-12 / 5\end{array}$ & $\begin{array}{l}\text { Acetaminophen } \\
\text { w/ Codeine Susp } \\
\text { 120-12 MG/5ML }\end{array}$ & 1 & 150 & 0.15 & 2.4 & 0.36 \\
\hline 65991002050310 & $\begin{array}{l}\text { APAP/CODEINE } \\
\text { TAB 300-15MG }\end{array}$ & $\begin{array}{l}\text { Acetaminophen } \\
\text { w/ Codeine Tab } \\
\text { 300-15 MG }\end{array}$ & 1 & 13 & 0.15 & 15 & 2.25 \\
\hline 65991002050315 & $\begin{array}{l}\text { APAP/CODEINE } \\
\text { TAB 300-30MG }\end{array}$ & $\begin{array}{l}\text { Acetaminophen } \\
\text { w/ Codeine Tab } \\
\text { 300-30 MG }\end{array}$ & 1 & 12 & 0.15 & 30 & 4.5 \\
\hline 65991002050320 & $\begin{array}{l}\text { APAP/CODEINE } \\
\text { TAB 300-60MG }\end{array}$ & $\begin{array}{l}\text { Acetaminophen } \\
\text { w/ Codeine Tab } \\
\text { 300-60 MG }\end{array}$ & 1 & 6 & 0.15 & 60 & 9 \\
\hline 65991303050120 & TREZIX CAP & $\begin{array}{l}\text { Acetaminophen- } \\
\text { Caffeine- } \\
\text { Dihydrocodeine } \\
\text { Cap 356.4-30 }\end{array}$ & 1 & 10 & 0.25 & 16 & 4 \\
\hline 65991303050340 & $\begin{array}{l}\text { APAP/CAFF/DI TAB } \\
\text { HYDROCOD }\end{array}$ & $\begin{array}{l}\text { Acetaminophen- } \\
\text { Caffeine- } \\
\text { Dihydrocodeine Tab } \\
712.8-60\end{array}$ & 1 & 5 & 0.25 & 32 & 8 \\
\hline 65200010100760 & $\begin{array}{l}\text { BUPRENORPHIN } \\
\text { SUB 2MG }\end{array}$ & $\begin{array}{l}\text { Buprenorphine } \mathrm{HCl} \\
\text { SL Tab } 2 \mathrm{MG} \\
\text { (Base Equiv) }\end{array}$ & 0 & 3 & 75 & 2 & 150 \\
\hline 65200010100780 & $\begin{array}{l}\text { BUPRENORPHIN } \\
\text { SUB 8MG }\end{array}$ & $\begin{array}{l}\text { Buprenorphine } \mathrm{HCl} \\
\text { SL Tab } 8 \mathrm{MG} \\
\text { (Base Equiv) }\end{array}$ & 0 & 3 & 75 & 8 & 600 \\
\hline 65200010208220 & $\begin{array}{l}\text { SUBOXONE MIS } \\
2-0.5 \mathrm{MG}\end{array}$ & $\begin{array}{l}\text { Buprenorphine } \\
\text { HCl-Naloxone } \\
\text { HCl SL Film } \\
\text { 2-0.5 MG (B }\end{array}$ & 0 & 3 & 75 & 2 & 150 \\
\hline 65200010208240 & $\begin{array}{l}\text { SUBOXONE MIS } \\
\text { 8-2MG }\end{array}$ & $\begin{array}{l}\text { Buprenorphine } \\
\text { HCl-Naloxone HCl } \\
\text { SL Film 8-2 MG } \\
\text { (Bas) }\end{array}$ & 0 & 3 & 75 & 8 & 600 \\
\hline 65200010200720 & $\begin{array}{l}\text { SUBOXONE SUB } \\
2-0.5 \mathrm{MG}\end{array}$ & $\begin{array}{l}\text { Buprenorphine } \mathrm{HCl}- \\
\text { Naloxone HCl SL } \\
\text { Tab 2-0.5 MG (Ba) }\end{array}$ & 0 & 3 & 75 & 2 & 150 \\
\hline 65200010200740 & $\begin{array}{l}\text { SUBOXONE SUB } \\
\text { 8-2MG }\end{array}$ & $\begin{array}{l}\text { Buprenorphine HCl- } \\
\text { Naloxone HCl SL } \\
\text { Tab 8-2 MG (Base) }\end{array}$ & 0 & 3 & 75 & 8 & 600 \\
\hline 65200010008830 & $\begin{array}{l}\text { BUTRANS DIS } \\
10 \mathrm{MCG} / \mathrm{HR}\end{array}$ & $\begin{array}{l}\text { Buprenorphine TD } \\
\text { Patch Weekly } 10 \\
\text { MCG/HR }\end{array}$ & 0 & 0.286 & 1800 & 0.01 & 18 \\
\hline 65200010008840 & $\begin{array}{l}\text { BUTRANS DIS } \\
\text { 20MCG/HR }\end{array}$ & $\begin{array}{l}\text { Buprenorphine TD } \\
\text { Patch Weekly } 20 \\
\text { MCG/HR }\end{array}$ & 0 & 0.143 & 1800 & 0.02 & 36 \\
\hline 65200010008820 & $\begin{array}{l}\text { BUTRANS DIS } \\
5 \mathrm{MCG} / \mathrm{HR}\end{array}$ & $\begin{array}{l}\text { Buprenorphine TD } \\
\text { Patch Weekly } 5 \\
\text { MCG/HR }\end{array}$ & 0 & 0.286 & 1800 & 0.005 & 9 \\
\hline 65991004100115 & $\begin{array}{l}\text { BUT/APAP/CAF } \\
\text { CAP CODEINE }\end{array}$ & $\begin{array}{l}\text { Butalbital- } \\
\text { Acetaminophen- } \\
\text { Caff w/ COD Cap } \\
\text { 50-325-40 }\end{array}$ & 1 & 6 & 0.15 & 30 & 4.5 \\
\hline 65991004300115 & $\begin{array}{l}\text { ASCOMP/COD } \\
\text { CAP 30MG }\end{array}$ & $\begin{array}{l}\text { Butalbital-Aspirin- } \\
\text { Caff w/ Codeine } \\
\text { Cap 50-325-40-3 }\end{array}$ & 1 & 6 & 0.15 & 30 & 4.5 \\
\hline 65100020200305 & $\begin{array}{l}\text { CODEINE SULF } \\
\text { TAB } 15 \mathrm{MG}\end{array}$ & $\begin{array}{l}\text { Codeine Sulfate Tab } \\
15 \mathrm{MG}\end{array}$ & 1 & 13 & 0.15 & 15 & 2.25 \\
\hline 65100020200310 & $\begin{array}{l}\text { CODEINE SULF } \\
\text { TAB 30MG }\end{array}$ & $\begin{array}{l}\text { Codeine Sulfate Tab } \\
30 \mathrm{MG}\end{array}$ & 1 & 12 & 0.15 & 30 & 4.5 \\
\hline 65100020200315 & $\begin{array}{l}\text { CODEINE SULF } \\
\text { TAB 60MG }\end{array}$ & $\begin{array}{l}\text { Codeine Sulfate Tab } \\
60 \mathrm{MG}\end{array}$ & 1 & 6 & 0.15 & 60 & 9 \\
\hline 65991303100115 & $\begin{array}{l}\text { SYNALGOS DC } \\
\text { CAP }\end{array}$ & $\begin{array}{l}\text { Dihydrocodeine } \\
\text { Compound Cap }\end{array}$ & 1 & 10 & 0.25 & 16 & 4 \\
\hline
\end{tabular}


Table 2. (continued)

\begin{tabular}{|c|c|c|c|c|c|c|c|}
\hline gpi_cd & drug_nm & gpi_nm & short_act & max_daily & morph_eqv_fctr & drg_strnth_mg & adj_dose \\
\hline 65100025100310 & $\begin{array}{l}\text { FENTORA TAB } \\
100 \mathrm{MCG}\end{array}$ & $\begin{array}{l}\text { Fentanyl Citrate } \\
\text { Buccal Tab } 100 \\
\text { MCG (Base Equiv) }\end{array}$ & 1 & 4 & 125 & 0.1 & 12.5 \\
\hline 65100025100320 & $\begin{array}{l}\text { FENTORA TAB } \\
\text { 200MCG }\end{array}$ & $\begin{array}{l}\text { Fentanyl Citrate } \\
\text { Buccal Tab 200 } \\
\text { MCG (Base Equiv) }\end{array}$ & 1 & 4 & 125 & 0.2 & 25 \\
\hline 65100025100330 & $\begin{array}{l}\text { FENTORA TAB } \\
\text { 400MCG }\end{array}$ & $\begin{array}{l}\text { Fentanyl Citrate } \\
\text { Buccal Tab } 400 \\
\text { MCG (Base Equiv) }\end{array}$ & 1 & 4 & 125 & 0.4 & 50 \\
\hline 65100025100340 & $\begin{array}{l}\text { FENTORA TAB } \\
\text { 600MCG }\end{array}$ & $\begin{array}{l}\text { Fentanyl Citrate } \\
\text { Buccal Tab } 600 \\
\text { MCG (Base Equiv) }\end{array}$ & 1 & 4 & 125 & 0.6 & 75 \\
\hline 65100025100350 & $\begin{array}{l}\text { FENTORA TAB } \\
\text { 800MCG }\end{array}$ & $\begin{array}{l}\text { Fentanyl Citrate } \\
\text { Buccal Tab 800 } \\
\text { MCG (Base Equiv) }\end{array}$ & 1 & 4 & 125 & 0.8 & 100 \\
\hline 65100025108475 & $\begin{array}{l}\text { FENTANYL OT LOZ } \\
1200 \mathrm{MCG}\end{array}$ & $\begin{array}{l}\text { Fentanyl Citrate } \\
\text { Lollipop } 1200 \mathrm{MCG}\end{array}$ & 1 & 4 & 125 & 1.2 & 150 \\
\hline 65100025108485 & $\begin{array}{l}\text { FENTANYL OT LOZ } \\
1600 \mathrm{MCG}\end{array}$ & $\begin{array}{l}\text { Fentanyl Citrate } \\
\text { Lollipop } 1600 \mathrm{MCG}\end{array}$ & 1 & 4 & 125 & 1.6 & 200 \\
\hline 65100025108450 & $\begin{array}{l}\text { FENTANYL OT LOZ } \\
200 \mathrm{MCG}\end{array}$ & $\begin{array}{l}\text { Fentanyl Citrate } \\
\text { Lollipop } 200 \mathrm{MCG}\end{array}$ & 1 & 4 & 125 & 0.2 & 25 \\
\hline 65100025108455 & $\begin{array}{l}\text { FENTANYL OT LOZ } \\
400 \mathrm{MCG}\end{array}$ & $\begin{array}{l}\text { Fentanyl Citrate } \\
\text { Lollipop } 400 \mathrm{MCG}\end{array}$ & 1 & 4 & 125 & 0.4 & 50 \\
\hline 65100025108460 & $\begin{array}{l}\text { FENTANYL OT LOZ } \\
600 \mathrm{MCG}\end{array}$ & $\begin{array}{l}\text { Fentanyl Citrate } \\
\text { Lollipop } 600 \mathrm{MCG}\end{array}$ & 1 & 4 & 125 & 0.6 & 75 \\
\hline 65100025108465 & $\begin{array}{l}\text { FENTANYL OT LOZ } \\
800 \mathrm{MCG}\end{array}$ & $\begin{array}{l}\text { Fentanyl Citrate } \\
\text { Lollipop } 800 \text { MCG }\end{array}$ & 1 & 4 & 125 & 0.8 & 100 \\
\hline 65100025100720 & $\begin{array}{l}\text { ABSTRAL SUB } \\
\text { 200MCG }\end{array}$ & $\begin{array}{l}\text { Fentanyl Citrate SL } \\
\text { Tab } 200 \text { MCG (Base } \\
\text { Equiv) }\end{array}$ & 1 & 4 & 125 & 0.2 & 25 \\
\hline 65100025000910 & $\begin{array}{l}\text { SUBSYS SPR } \\
100 \mathrm{MCG}\end{array}$ & $\begin{array}{l}\text { Fentanyl Sublingual } \\
\text { Spray } 100 \mathrm{MCG}\end{array}$ & 1 & 4 & 125 & 0.1 & 12.5 \\
\hline 65100025000920 & $\begin{array}{l}\text { SUBSYS SPR } \\
200 \mathrm{MCG}\end{array}$ & $\begin{array}{l}\text { Fentanyl Sublingual } \\
\text { Spray } 200 \mathrm{MCG}\end{array}$ & 1 & 4 & 125 & 0.2 & 25 \\
\hline 65100025008650 & $\begin{array}{l}\text { FENTANYL DIS } \\
100 \mathrm{MCG} / \mathrm{H}\end{array}$ & $\begin{array}{l}\text { Fentanyl TD Patch } \\
\text { 72HR } 100 \mathrm{MCG} / \\
\text { HR }\end{array}$ & 0 & 1.5 & 2400 & 0.1 & 240 \\
\hline 65100025008610 & $\begin{array}{l}\text { FENTANYL DIS } \\
12 \mathrm{MCG} / \mathrm{HR}\end{array}$ & $\begin{array}{l}\text { Fentanyl TD Patch } \\
72 \mathrm{HR} 12 \mathrm{MCG} / \mathrm{HR}\end{array}$ & 0 & 0.5 & 2400 & 0.0125 & 30 \\
\hline 65100025008620 & $\begin{array}{l}\text { FENTANYL DIS } \\
\text { 25MCG/HR }\end{array}$ & $\begin{array}{l}\text { Fentanyl TD Patch } \\
72 \mathrm{HR} 25 \mathrm{MCG} / \mathrm{HR}\end{array}$ & 0 & 0.5 & 2400 & 0.025 & 60 \\
\hline 65100025008630 & $\begin{array}{l}\text { FENTANYL DIS } \\
50 \mathrm{MCG} / \mathrm{HR}\end{array}$ & $\begin{array}{l}\text { Fentanyl TD Patch } \\
\text { 72HR } 50 \mathrm{MCG} / \mathrm{HR}\end{array}$ & 0 & 0.5 & 2400 & 0.05 & 120 \\
\hline 65100025008640 & $\begin{array}{l}\text { FENTANYL DIS } \\
75 \mathrm{MCG} / \mathrm{HR}\end{array}$ & $\begin{array}{l}\text { Fentanyl TD Patch } \\
72 \mathrm{HR} 75 \mathrm{MCG} / \mathrm{HR}\end{array}$ & 0 & 1 & 2400 & 0.075 & 180 \\
\hline 65991702100353 & $\begin{array}{l}\text { HYDROCO/APAP } \\
\text { TAB 10-750MG }\end{array}$ & $\begin{array}{l}\text { HYDROCO/APAP } \\
\text { TAB } 10-750 \mathrm{MG}\end{array}$ & 1 & 5 & 1 & 10 & 10 \\
\hline 65991702100110 & $\begin{array}{l}\text { STAGESIC CAP } \\
500-5 \mathrm{MG}\end{array}$ & $\begin{array}{l}\text { Hydrocodone- } \\
\text { Acetaminophen } \\
\text { Cap 5-500 MG }\end{array}$ & 1 & 8 & 1 & 5 & 5 \\
\hline 65991702102024 & $\begin{array}{l}\text { ZOLVIT SOL } \\
10-300 \mathrm{MG}\end{array}$ & $\begin{array}{l}\text { Hydrocodone- } \\
\text { Acetaminophen } \\
\text { Soln } 10-300 \\
\text { MG/15ML }\end{array}$ & 1 & 200 & 1 & 0.67 & 0.67 \\
\hline 65991702102025 & $\begin{array}{l}\text { ZAMICET SOL } \\
10-325 \mathrm{MG}\end{array}$ & $\begin{array}{l}\text { Hydrocodone- } \\
\text { Acetaminophen } \\
\text { Soln 10-325 } \\
\text { MG/15ML }\end{array}$ & 1 & 184.6 & 1 & 0.67 & 0.67 \\
\hline 65991702102015 & HYCET SOL 7.5-325 & $\begin{array}{l}\text { Hydrocodone- } \\
\text { Acetaminophen } \\
\text { Soln 7.5-325 } \\
\text { MG/15ML }\end{array}$ & 1 & 184.6 & 1 & 0.5 & 0.5 \\
\hline 65991702102020 & $\begin{array}{l}\text { HYDROCODONE/ } \\
\text { SOL APAP }\end{array}$ & $\begin{array}{l}\text { Hydrocodone- } \\
\text { Acetaminophen } \\
\text { Soln 7.5-500 } \\
\text { MG/15ML }\end{array}$ & 1 & 120 & 1 & 0.5 & 0.5 \\
\hline 65991702100375 & $\begin{array}{c}\text { XODOL TAB } \\
10-300 \mathrm{MG}\end{array}$ & $\begin{array}{l}\text { Hydrocodone- } \\
\text { Acetaminophen } \\
\text { Tab } 10-300 \mathrm{MG}\end{array}$ & 1 & 13 & 1 & 10 & 10 \\
\hline 65991702100305 & $\begin{array}{r}\text { HYDROCO/APAP } \\
\text { TAB 10-325MG }\end{array}$ & $\begin{array}{l}\text { Hydrocodone- } \\
\text { Acetaminophen } \\
\text { Tab 10-325 MG }\end{array}$ & 1 & 12 & 1 & 10 & 10 \\
\hline
\end{tabular}


Table 2. (continued)

\begin{tabular}{|c|c|c|c|c|c|c|c|}
\hline gpi_cd & drug_nm & gpi_nm & short_act & max_daily & morph_eqv_fctr & drg_strnth_mg & $\overline{\text { adj_dose }}$ \\
\hline 65991702100370 & $\begin{array}{l}\text { ZYDONE TAB } \\
10-400 \mathrm{MG}\end{array}$ & $\begin{array}{l}\text { Hydrocodone- } \\
\text { Acetaminophen } \\
\text { Tab } 10-400 \mathrm{MG}\end{array}$ & 1 & 10 & 1 & 10 & 10 \\
\hline 65991702100327 & $\begin{array}{l}\text { HYDROCO/APAP } \\
\text { TAB 10-500MG }\end{array}$ & $\begin{array}{l}\text { Hydrocodone- } \\
\text { Acetaminophen } \\
\text { Tab } 10-500 \mathrm{MG}\end{array}$ & 1 & 8 & 1 & 10 & 10 \\
\hline 65991702100345 & $\begin{array}{l}\text { HYDROCO/APAP } \\
\text { TAB 10-650MG }\end{array}$ & $\begin{array}{l}\text { Hydrocodone- } \\
\text { Acetaminophen Tab } \\
\text { 10-650 MG }\end{array}$ & 1 & 6 & 1 & 10 & 10 \\
\hline 65991702100346 & $\begin{array}{l}\text { HYDROCO/APAP } \\
\text { TAB 10-660MG }\end{array}$ & $\begin{array}{l}\text { Hydrocodone- } \\
\text { Acetaminophen Tab } \\
\text { 10-660 MG }\end{array}$ & 1 & 6 & 1 & 10 & 10 \\
\hline 65991702100307 & $\begin{array}{l}\text { HYDROCO/APAP } \\
\text { TAB 2.5-500 }\end{array}$ & $\begin{array}{l}\text { Hydrocodone- } \\
\text { Acetaminophen Tab } \\
2.5-500 \mathrm{MG}\end{array}$ & 1 & 8 & 1 & 2.5 & 2.5 \\
\hline 65991702100309 & $\begin{array}{l}\text { HYDROCO/APAP } \\
\text { TAB 5-300MG }\end{array}$ & $\begin{array}{l}\text { Hydrocodone- } \\
\text { Acetaminophen Tab } \\
\text { 5-300 MG }\end{array}$ & 1 & 13 & 1 & 5 & 5 \\
\hline 65991702100356 & $\begin{array}{l}\text { HYDROCO/APAP } \\
\text { TAB 5-325MG }\end{array}$ & $\begin{array}{l}\text { Hydrocodone- } \\
\text { Acetaminophen Tab } \\
\text { 5-325 MG }\end{array}$ & 1 & 12 & 1 & 5 & 5 \\
\hline 65991702100310 & $\begin{array}{l}\text { HYDROCO/APAP } \\
\text { TAB 5-500MG }\end{array}$ & $\begin{array}{l}\text { Hydrocodone- } \\
\text { Acetaminophen Tab } \\
\text { 5-500 MG }\end{array}$ & 1 & 8 & 1 & 5 & 5 \\
\hline 65991702100322 & XODOL TAB 7.5-300 & $\begin{array}{l}\text { Hydrocodone- } \\
\text { Acetaminophen Tab } \\
\text { 7.5-300 MG }\end{array}$ & 1 & 13 & 1 & 7.5 & 7.5 \\
\hline 65991702100358 & $\begin{array}{l}\text { HYDROCO/APAP } \\
\text { TAB 7.5-325 }\end{array}$ & $\begin{array}{l}\text { Hydrocodone- } \\
\text { Acetaminophen Tab } \\
\text { 7.5-325 MG }\end{array}$ & 1 & 12 & 1 & 7.5 & 7.5 \\
\hline 65991702100365 & $\begin{array}{l}\text { ZYDONE TAB } \\
7.5-400\end{array}$ & $\begin{array}{l}\text { Hydrocodone- } \\
\text { Acetaminophen Tab } \\
\text { 7.5-400 MG }\end{array}$ & 1 & 10 & 1 & 7.5 & 7.5 \\
\hline 65991702100325 & $\begin{array}{l}\text { HYDROCO/APAP } \\
\text { TAB 7.5-500 }\end{array}$ & $\begin{array}{l}\text { Hydrocodone- } \\
\text { Acetaminophen Tab } \\
\text { 7.5-500 MG }\end{array}$ & 1 & 8 & 1 & 7.5 & 7.5 \\
\hline 65991702100340 & $\begin{array}{l}\text { HYDROCO/APAP } \\
\text { TAB } 7.5-650\end{array}$ & $\begin{array}{l}\text { Hydrocodone- } \\
\text { Acetaminophen Tab } \\
\text { 7.5-650 MG }\end{array}$ & 1 & 6 & 1 & 7.5 & 7.5 \\
\hline 65991702100350 & $\begin{array}{l}\text { HYDROCO/APAP } \\
\text { TAB 7.5-750 }\end{array}$ & $\begin{array}{l}\text { Hydrocodone- } \\
\text { Acetaminophen Tab } \\
\text { 7.5-750 MG }\end{array}$ & 1 & 5 & 1 & 7.5 & 7.5 \\
\hline 65991702500330 & $\begin{array}{l}\text { REPREXAIN TAB } \\
\text { 10-200MG }\end{array}$ & $\begin{array}{l}\text { Hydrocodone- } \\
\text { Ibuprofen Tab } \\
10-200 \mathrm{MG}\end{array}$ & 1 & 5 & 1 & 10 & 10 \\
\hline 65991702500310 & $\begin{array}{l}\text { REPREXAIN TAB } \\
2.5-200\end{array}$ & $\begin{array}{l}\text { Hydrocodone- } \\
\text { Ibuprofen Tab } \\
2.5-200 \mathrm{MG}\end{array}$ & 1 & 5 & 1 & 2.5 & 2.5 \\
\hline 65991702500315 & $\begin{array}{l}\text { HYDROCOD/IBU } \\
\text { TAB 5-200MG }\end{array}$ & $\begin{array}{l}\text { Hydrocodone- } \\
\text { Ibuprofen Tab } \\
\text { 5-200 MG }\end{array}$ & 1 & 5 & 1 & 5 & 5 \\
\hline 65991702500320 & $\begin{array}{l}\text { HYDROCOD/IBU } \\
\text { TAB 7.5-200 }\end{array}$ & $\begin{array}{l}\text { Hydrocodone- } \\
\text { Ibuprofen Tab } \\
7.5-200 \mathrm{MG}\end{array}$ & 1 & 5 & 1 & 7.5 & 7.5 \\
\hline 65100035100920 & $\begin{array}{l}\text { HYDROMORPHON } \\
\text { LIQ 1MG/ML }\end{array}$ & $\begin{array}{l}\text { Hydromorphone } \mathrm{HCl} \\
\text { Liqd } 1 \mathrm{MG} / \mathrm{ML}\end{array}$ & 1 & 480 & 4 & 1 & 4 \\
\hline 65100035105205 & $\begin{array}{l}\text { HYDROMORPHON } \\
\text { SUP 3MG }\end{array}$ & $\begin{array}{l}\text { Hydromorphone } \mathrm{HCl} \\
\text { Suppos } 3 \mathrm{MG}\end{array}$ & 1 & 12 & 4 & 3 & 12 \\
\hline 65100035100310 & $\begin{array}{l}\text { HYDROMORPHON } \\
\text { TAB 2MG }\end{array}$ & $\begin{array}{l}\text { Hydromorphone } \mathrm{HCl} \\
\text { Tab } 2 \mathrm{MG}\end{array}$ & 1 & 16 & 4 & 2 & 8 \\
\hline 65100035100320 & $\begin{array}{l}\text { HYDROMORPHON } \\
\text { TAB 4MG }\end{array}$ & $\begin{array}{l}\text { Hydromorphone } \mathrm{HCl} \\
\text { Tab } 4 \text { MG }\end{array}$ & 1 & 8 & 4 & 4 & 16 \\
\hline 65100035100330 & $\begin{array}{l}\text { HYDROMORPHON } \\
\text { TAB 8MG }\end{array}$ & $\begin{array}{l}\text { Hydromorphone } \mathrm{HCl} \\
\text { Tab } 8 \mathrm{MG}\end{array}$ & 1 & 4 & 4 & 8 & 32 \\
\hline 65100035107530 & EXALGO TAB 12MG & $\begin{array}{l}\text { Hydromorphone } \mathrm{HCl} \\
\text { Tab SR 24HR } 12 \\
\text { MG }\end{array}$ & 0 & 2 & 4 & 12 & 48 \\
\hline 65100035107540 & EXALGO TAB 16MG & $\begin{array}{l}\text { Hydromorphone } \mathrm{HCl} \\
\text { Tab SR 24HR } 16 \\
\text { MG }\end{array}$ & 0 & 2 & 4 & 16 & 64 \\
\hline
\end{tabular}


Table 2. (continued)

\begin{tabular}{|c|c|c|c|c|c|c|c|}
\hline gpi_cd & drug_nm & gpi_nm & short_act & max_daily & morph_eqv_fctr & drg_strnth_mg & adj_dose \\
\hline 65100035107555 & EXALGO TAB 32MG & $\begin{array}{l}\text { Hydromorphone } \mathrm{HCl} \\
\text { Tab SR 24HR } 32 \\
\text { MG }\end{array}$ & 0 & & 4 & 32 & 128 \\
\hline 65100035107520 & EXALGO TAB 8MG & $\begin{array}{l}\text { Hydromorphone } \mathrm{HCl} \\
\text { Tab SR 24HR } 8 \\
\text { MG }\end{array}$ & 0 & 4 & 4 & 8 & 32 \\
\hline 65100045102060 & $\begin{array}{l}\text { MEPERIDINE SOL } \\
50 \mathrm{MG} / 5 \mathrm{ML}\end{array}$ & $\begin{array}{l}\text { Meperidine } \mathrm{HCl} \text { Oral } \\
\text { Soln } 50 \mathrm{MG} / 5 \mathrm{ML}\end{array}$ & 1 & 60 & 0.1 & 10 & 1 \\
\hline 65100045100310 & $\begin{array}{l}\text { MEPERITAB TAB } \\
\text { 100MG }\end{array}$ & $\begin{array}{l}\text { Meperidine } \mathrm{HCl} \mathrm{Tab} \\
100 \mathrm{MG}\end{array}$ & 1 & 6 & 0.1 & 100 & 10 \\
\hline 65100045100305 & $\begin{array}{l}\text { MEPERITAB TAB } \\
50 \mathrm{MG}\end{array}$ & $\begin{array}{l}\text { Meperidine } \mathrm{HCl} \text { Tab } \\
50 \mathrm{MG}\end{array}$ & 1 & 12 & 0.1 & 50 & 5 \\
\hline 65993002200110 & $\begin{array}{l}\text { MEPROZINE CAP } \\
\text { 50-25MG }\end{array}$ & $\begin{array}{l}\text { Meperidine w/ } \\
\text { Promethazine Cap } \\
50-25 \mathrm{MG}\end{array}$ & 1 & 12 & 0.1 & 50 & 5 \\
\hline 65100050101310 & $\begin{array}{l}\text { METHADONE CON } \\
\text { 10MG/ML }\end{array}$ & $\begin{array}{l}\text { Methadone } \mathrm{HCl} \text { Conc } \\
10 \mathrm{MG} / \mathrm{ML}\end{array}$ & 1 & 40 & 3 & 10 & 30 \\
\hline 65100050102015 & $\begin{array}{l}\text { METHADONE SOL } \\
10 \mathrm{MG} / 5 \mathrm{ML}\end{array}$ & $\begin{array}{l}\text { Methadone HCl Soln } \\
10 \mathrm{MG} / 5 \mathrm{ML}\end{array}$ & 1 & 200 & 3 & 2 & 6 \\
\hline 65100050102010 & $\begin{array}{l}\text { METHADONE SOL } \\
5 \mathrm{MG} / 5 \mathrm{ML}\end{array}$ & $\begin{array}{l}\text { Methadone HCl Soln } \\
5 \mathrm{MG} / 5 \mathrm{ML}\end{array}$ & 1 & 400 & 3 & 1 & 3 \\
\hline 65100050100310 & $\begin{array}{l}\text { METHADONE TAB } \\
\text { 10MG }\end{array}$ & $\begin{array}{l}\text { Methadone } \mathrm{HCl} \mathrm{Tab} \\
10 \mathrm{MG}\end{array}$ & 1 & 40 & 3 & 10 & 30 \\
\hline 65100050100305 & $\begin{array}{l}\text { METHADONE TAB } \\
\text { 5MG }\end{array}$ & $\begin{array}{l}\text { Methadone } \mathrm{HCl} \mathrm{Tab} \\
5 \mathrm{MG}\end{array}$ & 1 & 80 & 3 & 5 & 15 \\
\hline 65100050107320 & $\begin{array}{l}\text { METHADONE TAB } \\
\text { 40MG }\end{array}$ & $\begin{array}{l}\text { Methadone } \mathrm{HCl} \text { Tab } \\
\text { For Oral Susp } 40 \\
\text { MG }\end{array}$ & 1 & 10 & 3 & 40 & 120 \\
\hline 65100055107480 & $\begin{array}{l}\text { MORPHINE SUL } \\
\text { TAB 200MG ER }\end{array}$ & $\begin{array}{l}\text { MORPHINE SUL } \\
\text { TAB 200MG ER }\end{array}$ & 0 & & 1 & 200 & 200 \\
\hline 65100055102090 & $\begin{array}{l}\text { MORPHINE SUL } \\
\text { SOL 20MG/ML }\end{array}$ & $\begin{array}{l}\text { Morphine Sulfate } \\
\text { (Concentrate) Oral } \\
\text { Soln } 20 \mathrm{MG} / \mathrm{ML}\end{array}$ & 1 & 36 & 1 & 20 & 20 \\
\hline 65100055207050 & $\begin{array}{l}\text { AVINZA CAP } \\
120 \mathrm{MG} \mathrm{ER}\end{array}$ & $\begin{array}{l}\text { Morphine Sulfate } \\
\text { Beads Cap SR } \\
\text { 24HR 120 MG }\end{array}$ & 0 & 13 & 1 & 120 & 120 \\
\hline 65100055207020 & $\begin{array}{l}\text { AVINZA CAP } \\
30 \mathrm{MG}\end{array}$ & $\begin{array}{c}\text { Morphine Sulfate } \\
\text { Beads Cap SR } \\
\text { 24HR } 30 \mathrm{MG}\end{array}$ & 0 & 1 & 1 & 30 & 30 \\
\hline 65100055207025 & $\begin{array}{l}\text { AVINZA CAP } \\
45 \mathrm{MG}\end{array}$ & $\begin{array}{c}\text { Morphine Sulfate } \\
\text { Beads Cap SR } \\
\text { 24HR 45 MG }\end{array}$ & 0 & 1 & 1 & 45 & 45 \\
\hline 65100055207030 & $\begin{array}{l}\text { AVINZA CAP } \\
\text { 60MG CR }\end{array}$ & $\begin{array}{l}\text { Morphine Sulfate } \\
\text { Beads Cap SR } \\
\text { 24HR } 60 \text { MG }\end{array}$ & 0 & 1 & 1 & 60 & 60 \\
\hline 65100055207035 & $\begin{array}{l}\text { AVINZA CAP } \\
75 \mathrm{MG}\end{array}$ & $\begin{array}{c}\text { Morphine Sulfate } \\
\text { Beads Cap SR } \\
\text { 24HR } 75 \text { MG }\end{array}$ & 0 & 21 & 1 & 75 & 75 \\
\hline 65100055207040 & $\begin{array}{l}\text { AVINZA CAP } \\
\text { 90MG CR }\end{array}$ & $\begin{array}{l}\text { Morphine Sulfate } \\
\text { Beads Cap SR } \\
\text { 24HR } 90 \text { MG }\end{array}$ & 0 & 17 & 1 & 90 & 90 \\
\hline 65100055107010 & $\begin{array}{l}\text { KADIAN CAP } \\
10 \mathrm{MG} \mathrm{CR}\end{array}$ & $\begin{array}{l}\text { Morphine Sulfate Cap } \\
\text { SR 24HR } \\
10 \mathrm{MG}\end{array}$ & 0 & 1 & 1 & 10 & 10 \\
\hline 65100055107060 & $\begin{array}{l}\text { KADIAN CAP } \\
\text { 100MG CR }\end{array}$ & $\begin{array}{l}\text { Morphine Sulfate Cap } \\
\text { SR 24HR } \\
100 \mathrm{MG}\end{array}$ & 0 & 1 & 1 & 100 & 100 \\
\hline 65100055107020 & $\begin{array}{l}\text { KADIAN CAP } \\
\text { 20MG CR }\end{array}$ & $\begin{array}{l}\text { Morphine Sulfate Cap } \\
\text { SR 24HR } \\
20 \mathrm{MG}\end{array}$ & 0 & 2 & 1 & 20 & 20 \\
\hline 65100055107030 & $\begin{array}{l}\text { KADIAN CAP } \\
\text { 30MG CR }\end{array}$ & $\begin{array}{l}\text { Morphine Sulfate Cap } \\
\text { SR 24HR } \\
30 \mathrm{MG}\end{array}$ & 0 & 1 & 1 & 30 & 30 \\
\hline 65100055107040 & $\begin{array}{l}\text { KADIAN CAP } \\
50 \mathrm{MG} \mathrm{CR}\end{array}$ & $\begin{array}{l}\text { Morphine Sulfate Cap } \\
\text { SR 24HR } \\
50 \mathrm{MG}\end{array}$ & 0 & 1 & 1 & 50 & 50 \\
\hline 65100055107045 & $\begin{array}{l}\text { KADIAN CAP } \\
\text { 60MG CR }\end{array}$ & $\begin{array}{l}\text { Morphine Sulfate Cap } \\
\text { SR 24HR } \\
60 \mathrm{MG}\end{array}$ & 0 & 1 & 1 & 60 & 60 \\
\hline
\end{tabular}


Table 2. (continued)

\begin{tabular}{|c|c|c|c|c|c|c|c|}
\hline$\overline{\text { gpi_cd }}$ & drug_nm & gpi_nm & short_act & max_daily & morph_eqv_fctr & drg_strnth_mg & adj_dose \\
\hline 65100055107050 & $\begin{array}{l}\text { KADIAN CAP } \\
80 \mathrm{MG} \mathrm{CR}\end{array}$ & $\begin{array}{c}\text { Morphine Sulfate Cap } \\
\text { SR 24HR } 80 \mathrm{MG}\end{array}$ & 0 & 1 & 1 & 80 & 80 \\
\hline 65100055102065 & $\begin{array}{l}\text { MORPHINE SUL } \\
\text { SOL 10MG/5ML }\end{array}$ & $\begin{array}{l}\text { Morphine Sulfate } \\
\text { Oral Soln } 10 \\
\text { MG/5ML }\end{array}$ & 1 & 480 & 1 & 2 & 2 \\
\hline 65100055102070 & $\begin{array}{l}\text { MORPHINE SUL } \\
\text { SOL 20MG/5ML }\end{array}$ & $\begin{array}{l}\text { Morphine Sulfate } \\
\text { Oral Soln } \\
20 \mathrm{MG} / 5 \mathrm{ML}\end{array}$ & 1 & 240 & 1 & 4 & 4 \\
\hline 65100055100310 & $\begin{array}{l}\text { MORPHINE SUL } \\
\text { TAB } 15 \mathrm{MG}\end{array}$ & $\begin{array}{l}\text { Morphine Sulfate Tab } \\
15 \mathrm{MG}\end{array}$ & 1 & 12 & 1 & 15 & 15 \\
\hline 65100055100315 & $\begin{array}{l}\text { MORPHINE SUL } \\
\text { TAB 30MG }\end{array}$ & $\begin{array}{l}\text { Morphine Sulfate Tab } \\
30 \mathrm{MG}\end{array}$ & 1 & 6 & 1 & 30 & 30 \\
\hline 65100055107314 & $\begin{array}{l}\text { MORPHINE SUL } \\
\text { TAB 10MG }\end{array}$ & $\begin{array}{l}\text { Morphine Sulfate Tab } \\
\text { Sol } 10 \mathrm{MG}\end{array}$ & 1 & 480 & 1 & 10 & 10 \\
\hline 65100055107460 & $\begin{array}{l}\text { MORPHINE SUL } \\
\text { TAB 100MG ER }\end{array}$ & $\begin{array}{c}\text { Morphine Sulfate Tab } \\
\text { SR } 12 \mathrm{HR} 100 \mathrm{MG}\end{array}$ & 0 & 3 & 1 & 100 & 100 \\
\hline 65100055107415 & $\begin{array}{l}\text { MORPHINE SUL } \\
\text { TAB 15MG ER }\end{array}$ & $\begin{array}{l}\text { Morphine Sulfate Tab } \\
\text { SR } 12 \mathrm{HR} 15 \mathrm{MG}\end{array}$ & 0 & 3 & 1 & 15 & 15 \\
\hline 65100055107430 & $\begin{array}{l}\text { MORPHINE SUL } \\
\text { TAB 30MG CR }\end{array}$ & $\begin{array}{l}\text { Morphine Sulfate Tab } \\
\text { SR } 12 \mathrm{HR} 30 \mathrm{MG}\end{array}$ & 0 & 3 & 1 & 30 & 30 \\
\hline 65100055107445 & $\begin{array}{l}\text { MORPHINE SUL } \\
\text { TAB 60MG ER }\end{array}$ & $\begin{array}{l}\text { Morphine Sulfate Tab } \\
\text { SR } 12 \mathrm{HR} 60 \mathrm{MG}\end{array}$ & 0 & 3 & 1 & 60 & 60 \\
\hline 65100055700270 & $\begin{array}{l}\text { EMBEDA CAP } \\
100-4 \mathrm{MG}\end{array}$ & $\begin{array}{l}\text { Morphine-Naltrexone } \\
\text { Cap CR 100-4 MG }\end{array}$ & 0 & & 1 & 100 & 100 \\
\hline 65100055700220 & $\begin{array}{l}\text { EMBEDA CAP } \\
20-0.8 \mathrm{MG}\end{array}$ & $\begin{array}{l}\text { Morphine-Naltrexone } \\
\text { Cap CR 20-0.8 MG }\end{array}$ & 0 & 4 & 1 & 20 & 20 \\
\hline 65100055700230 & $\begin{array}{l}\text { EMBEDA CAP } \\
30-1.2 \mathrm{MG}\end{array}$ & $\begin{array}{l}\text { Morphine-Naltrexone } \\
\text { Cap CR 30-1.2 MG }\end{array}$ & 0 & 6 & 1 & 30 & 30 \\
\hline 65100055700240 & $\begin{array}{l}\text { EMBEDA CAP } \\
50-2 \mathrm{MG}\end{array}$ & $\begin{array}{l}\text { Morphine-Naltrexone } \\
\text { Cap CR 50-2 MG }\end{array}$ & 0 & 2 & 1 & 50 & 50 \\
\hline 65100055700250 & $\begin{array}{l}\text { EMBEDA CAP } \\
60-2.4 \mathrm{MG}\end{array}$ & $\begin{array}{l}\text { Morphine-Naltrexone } \\
\text { Cap CR 60-2.4 MG }\end{array}$ & 0 & 4 & 1 & 60 & 60 \\
\hline 65100055700260 & $\begin{array}{l}\text { EMBEDA CAP } \\
80-3.2 \mathrm{MG}\end{array}$ & $\begin{array}{l}\text { Morphine-Naltrexone } \\
\text { Cap CR 80-3.2 MG }\end{array}$ & 0 & & 1 & 80 & 80 \\
\hline 65990002200337 & $\begin{array}{l}\text { NARVOX TAB } \\
10-500 \mathrm{MG}\end{array}$ & $\begin{array}{l}\text { NARVOX TAB } 10- \\
500 \mathrm{MG}\end{array}$ & 1 & 8 & 1.5 & 10 & 15 \\
\hline 65100075100110 & OXYIR CAP 5MG & $\begin{array}{l}\text { Oxycodone } \mathrm{HCl} \text { Cap } \\
5 \mathrm{MG}\end{array}$ & 1 & 18 & 1.5 & 5 & 7.5 \\
\hline 65100075101320 & $\begin{array}{l}\text { ETH-OXYDOSE } \\
\text { CON 20MG/ML }\end{array}$ & $\begin{array}{l}\text { Oxycodone } \mathrm{HCl} \\
\text { Conc } 20 \mathrm{MG} / \mathrm{ML}\end{array}$ & 1 & 36 & 1.5 & 20 & 30 \\
\hline 65100075102005 & $\begin{array}{l}\text { OXYCODONE SOL } \\
5 \mathrm{MG} / 5 \mathrm{ML}\end{array}$ & $\begin{array}{l}\text { Oxycodone } \mathrm{HCl} \text { Soln } \\
5 \mathrm{MG} / 5 \mathrm{ML}\end{array}$ & 1 & 360 & 1.5 & 1 & 1.5 \\
\hline 65100075100320 & $\begin{array}{l}\text { OXYCODONE TAB } \\
10 \mathrm{MG}\end{array}$ & $\begin{array}{l}\text { Oxycodone } \mathrm{HCl} \mathrm{Tab} \\
10 \mathrm{MG}\end{array}$ & 1 & 12 & 1.5 & 10 & 15 \\
\hline 65100075100325 & $\begin{array}{l}\text { OXYCODONE TAB } \\
15 \mathrm{MG}\end{array}$ & $\begin{array}{l}\text { Oxycodone } \mathrm{HCl} \text { Tab } \\
15 \mathrm{MG}\end{array}$ & 1 & 12 & 1.5 & 15 & 22.5 \\
\hline 65100075100330 & $\begin{array}{l}\text { OXYCODONE TAB } \\
\text { 20MG }\end{array}$ & $\begin{array}{l}\text { Oxycodone } \mathrm{HCl} \text { Tab } \\
20 \mathrm{MG}\end{array}$ & 1 & 12 & 1.5 & 20 & 30 \\
\hline 65100075100340 & $\begin{array}{l}\text { OXYCODONE TAB } \\
\text { 30MG }\end{array}$ & $\begin{array}{l}\text { Oxycodone } \mathrm{HCl} \text { Tab } \\
30 \mathrm{MG}\end{array}$ & 1 & 24 & 1.5 & 30 & 45 \\
\hline 65100075100310 & $\begin{array}{l}\text { OXYCODONE TAB } \\
5 \mathrm{MG}\end{array}$ & $\begin{array}{l}\text { Oxycodone } \mathrm{HCl} \mathrm{Tab} \\
5 \mathrm{MG}\end{array}$ & 1 & 18 & 1.5 & 5 & 7.5 \\
\hline 65100075107410 & $\begin{array}{l}\text { OXYCONTIN TAB } \\
\text { 10MG CR }\end{array}$ & $\begin{array}{c}\text { Oxycodone } \mathrm{HCl} \text { Tab } \\
\text { SR } 12 \mathrm{HR} 10 \mathrm{MG}\end{array}$ & 0 & 3 & 1.5 & 10 & 15 \\
\hline 65100075107415 & $\begin{array}{l}\text { OXYCONTIN TAB } \\
15 \mathrm{MG} \mathrm{CR}\end{array}$ & $\begin{array}{c}\text { Oxycodone } \mathrm{HCl} \text { Tab } \\
\text { SR } 12 \mathrm{HR} 15 \mathrm{MG}\end{array}$ & 0 & 3 & 1.5 & 15 & 22.5 \\
\hline 65100075107420 & $\begin{array}{l}\text { OXYCONTIN TAB } \\
20 \mathrm{MG} \mathrm{CR}\end{array}$ & $\begin{array}{c}\text { Oxycodone } \mathrm{HCl} \mathrm{Tab} \\
\text { SR 12HR } 20 \mathrm{MG}\end{array}$ & 0 & 3 & 1.5 & 20 & 30 \\
\hline 65100075107430 & $\begin{array}{l}\text { OXYCONTIN TAB } \\
\text { 30MG CR }\end{array}$ & $\begin{array}{c}\text { Oxycodone } \mathrm{HCl} \text { Tab } \\
\text { SR } 12 \mathrm{HR} 30 \mathrm{MG}\end{array}$ & 0 & 3 & 1.5 & 30 & 45 \\
\hline 65100075107440 & $\begin{array}{l}\text { OXYCONTIN TAB } \\
40 \mathrm{MG} \mathrm{CR}\end{array}$ & $\begin{array}{c}\text { Oxycodone } \mathrm{HCl} \text { Tab } \\
\text { SR } 12 \mathrm{HR} 40 \mathrm{MG}\end{array}$ & 0 & 3 & 1.5 & 40 & 60 \\
\hline 65100075107460 & $\begin{array}{l}\text { OXYCONTIN TAB } \\
\text { 60MG CR }\end{array}$ & $\begin{array}{c}\text { Oxycodone } \mathrm{HCl} \mathrm{Tab} \\
\text { SR } 12 \mathrm{HR} 60 \mathrm{MG}\end{array}$ & 0 & 3 & 1.5 & 60 & 90 \\
\hline 65100075107480 & $\begin{array}{l}\text { OXYCONTIN TAB } \\
\text { 80MG CR }\end{array}$ & $\begin{array}{l}\text { Oxycodone } \mathrm{HCl} \text { Tab } \\
\text { SR } 12 \mathrm{HR} 80 \mathrm{MG}\end{array}$ & 0 & 8 & 1.5 & 80 & 120 \\
\hline 65990002200120 & $\begin{array}{l}\text { OXYCOD/APAP CAP } \\
\text { 5-500MG }\end{array}$ & $\begin{array}{l}\text { Oxycodone w/ Acet- } \\
\text { aminophen Cap } \\
\text { 5-500 MG }\end{array}$ & 1 & 8 & 1.5 & 5 & 7.5 \\
\hline 65990002202005 & $\begin{array}{l}\text { ROXICET SOL } \\
5-325 / 5\end{array}$ & $\begin{array}{l}\text { Oxycodone w/ Acet- } \\
\text { aminophen Soln } \\
\text { 5-325 MG/5ML }\end{array}$ & 1 & 65 & 1.5 & 1 & 1.5 \\
\hline
\end{tabular}


Table 2. (continued)

\begin{tabular}{|c|c|c|c|c|c|c|c|}
\hline $\begin{array}{l}\text { gpi_cd } \\
\text {. }\end{array}$ & drug_nm & gpi_nm & short_act & max_daily & morph_eqv_fctr & drg_strnth_mg & $\overline{\text { adj_dose }}$ \\
\hline 65990002200333 & $\begin{array}{l}\text { PRIMLEV TAB } \\
10-300 \mathrm{MG}\end{array}$ & $\begin{array}{l}\text { Oxycodone w/ Acet- } \\
\text { aminophen Tab } \\
\text { 10-300 MG }\end{array}$ & 1 & 13 & 1.5 & 10 & 15 \\
\hline 65990002200335 & $\begin{array}{l}\text { OXYCOD/APAP } \\
\text { TAB } 10-325 \mathrm{MG}\end{array}$ & $\begin{array}{l}\text { Oxycodone w/ Acet- } \\
\text { aminophen Tab } \\
\text { 10-325 MG }\end{array}$ & 1 & 12 & 1.5 & 10 & 15 \\
\hline 65990002200336 & $\begin{array}{l}\text { MAGNACET TAB } \\
10-400 \mathrm{MG}\end{array}$ & $\begin{array}{l}\text { Oxycodone w/ Acet- } \\
\text { aminophen Tab } \\
\text { 10-400 MG }\end{array}$ & 1 & 10 & 1.5 & 10 & 15 \\
\hline 65990002200340 & $\begin{array}{l}\text { OXYCOD/APAP } \\
\text { TAB 10-650MG }\end{array}$ & $\begin{array}{l}\text { Oxycodone w/ Acet- } \\
\text { aminophen Tab } \\
\text { 10-650 MG }\end{array}$ & 1 & 6 & 1.5 & 10 & 15 \\
\hline 65990002200305 & $\begin{array}{l}\text { OXYCOD/APAP } \\
\text { TAB 2.5-325 }\end{array}$ & $\begin{array}{l}\text { Oxycodone w/ Acet- } \\
\text { aminophen Tab } \\
2.5-325 \mathrm{MG}\end{array}$ & 1 & 12 & 1.5 & 2.5 & 3.75 \\
\hline 65990002200308 & $\begin{array}{l}\text { PRIMALEV TAB } \\
\text { 5-300 }\end{array}$ & $\begin{array}{l}\text { Oxycodone w/ Acet- } \\
\text { aminophen Tab } \\
\text { 5-300 MG }\end{array}$ & 1 & 12 & 1.5 & 5 & 7.5 \\
\hline 65990002200310 & $\begin{array}{l}\text { OXYCOD/APAP TAB } \\
5-325 \mathrm{MG}\end{array}$ & $\begin{array}{l}\text { Oxycodone w/ } \\
\text { Acetaminophen Tab } \\
\text { 5-325 MG }\end{array}$ & 1 & 12 & 1.5 & 5 & 7.5 \\
\hline 65990002200315 & $\begin{array}{l}\text { MAGNACET TAB } \\
\text { 5-400MG }\end{array}$ & $\begin{array}{l}\text { Oxycodone w/ Acet- } \\
\text { aminophen Tab } \\
\text { 5-400 MG }\end{array}$ & 1 & 10 & 1.5 & 5 & 7.5 \\
\hline 65990002200325 & $\begin{array}{l}\text { PRIMALEV TAB } \\
7.5-300\end{array}$ & $\begin{array}{l}\text { Oxycodone w/ Acet- } \\
\text { aminophen Tab } \\
\text { 7.5-300 MG }\end{array}$ & 1 & 13 & 1.5 & 7.5 & 11.25 \\
\hline 65990002200327 & $\begin{array}{l}\text { OXYCOD-APAP } \\
\text { TAB } 7.5-325\end{array}$ & $\begin{array}{l}\text { Oxycodone w/ Acet- } \\
\text { aminophen Tab } \\
\text { 7.5-325 MG }\end{array}$ & 1 & 12 & 1.5 & 7.5 & 11.25 \\
\hline 65990002200328 & $\begin{array}{l}\text { MAGNACET TAB } \\
\quad 7.5-400\end{array}$ & $\begin{array}{l}\text { Oxycodone w/ Acet- } \\
\text { aminophen Tab } \\
\text { 7.5-400 MG }\end{array}$ & 1 & 10 & 1.5 & 7.5 & 11.25 \\
\hline 65990002200330 & $\begin{array}{l}\text { OXYCOD/APAP TAB } \\
7.5-500\end{array}$ & $\begin{array}{l}\text { Oxycodone w/ Acet- } \\
\text { aminophen Tab } \\
7.5-500 \mathrm{MG}\end{array}$ & 1 & 8 & 1.5 & 7.5 & 11.25 \\
\hline 65990002220320 & PERCODAN TAB & $\begin{array}{l}\text { Oxycodone w/ } \\
\text { Aspirin Tab Full } \\
\text { Strength }\end{array}$ & 1 & 12 & 1.5 & 4.8355 & 7.25325 \\
\hline 65990002220340 & OXYCOD/ASA TAB & $\begin{array}{l}\text { Oxycodone-Aspirin } \\
\text { Tab 4.8355-325 } \\
\text { MG }\end{array}$ & 1 & 12 & 1.5 & 4.8355 & 7.25325 \\
\hline 65990002260320 & $\begin{array}{l}\text { OXYCOD/IBU TAB } \\
5-400 \mathrm{MG}\end{array}$ & $\begin{array}{l}\text { Oxycodone-Ibuprofen } \\
\text { Tab 5-400 MG }\end{array}$ & 1 & 4 & 1.5 & 5 & 7.5 \\
\hline 65100080100310 & $\begin{array}{l}\text { OXYMORPHONE } \\
\text { TAB HCL 10MG }\end{array}$ & $\begin{array}{l}\text { Oxymorphone } \mathrm{HCl} \\
\text { Tab } 10 \mathrm{MG}\end{array}$ & 1 & 24 & 3 & 10 & 30 \\
\hline 65100080100305 & $\begin{array}{l}\text { OXYMORPHONE } \\
\text { TAB HCL 5MG }\end{array}$ & $\begin{array}{l}\text { Oxymorphone } \mathrm{HCl} \\
\text { Tab } 5 \mathrm{MG}\end{array}$ & 1 & 24 & 3 & 5 & 15 \\
\hline 65100080107410 & $\begin{array}{l}\text { OPANA ER TAB } \\
\text { 10MG }\end{array}$ & $\begin{array}{l}\text { Oxymorphone } \mathrm{HCl} \\
\text { Tab SR 12HR } 10 \\
\text { MG }\end{array}$ & 0 & 3 & 3 & 10 & 30 \\
\hline 65100080107465 & $\begin{array}{l}\text { OPANA ER TAB } \\
\text { 10MG }\end{array}$ & $\begin{array}{l}\text { Oxymorphone } \mathrm{HCl} \\
\text { Tab SR 12HR } 10 \\
\text { MG (Crush } \\
\text { Resistant) }\end{array}$ & 0 & 3 & 3 & 10 & 30 \\
\hline 65100080107415 & $\begin{array}{l}\text { OPANA ER TAB } \\
15 \mathrm{MG}\end{array}$ & $\begin{array}{l}\text { Oxymorphone } \mathrm{HCl} \\
\text { Tab SR 12HR } 15 \\
\text { MG }\end{array}$ & 0 & 3 & 3 & 15 & 45 \\
\hline 65100080107420 & $\begin{array}{l}\text { OPANA ER TAB } \\
20 \mathrm{MG}\end{array}$ & $\begin{array}{l}\text { Oxymorphone } \mathrm{HCl} \\
\text { Tab SR 12HR } 20 \\
\text { MG }\end{array}$ & 0 & 3 & 3 & 20 & 60 \\
\hline 65100080107475 & $\begin{array}{l}\text { OPANA ER TAB } \\
20 \mathrm{MG}\end{array}$ & $\begin{array}{l}\text { Oxymorphone HCl } \\
\text { Tab SR 12HR } 20 \\
\text { MG (Crush } \\
\text { Resistant) }\end{array}$ & 0 & 3 & 3 & 20 & 60 \\
\hline 65100080107430 & $\begin{array}{l}\text { OPANA ER TAB } \\
30 \mathrm{MG}\end{array}$ & $\begin{array}{l}\text { Oxymorphone } \mathrm{HCl} \\
\text { Tab SR 12HR } 30 \\
\text { MG }\end{array}$ & 0 & 3 & 3 & 30 & 90 \\
\hline 65100080107480 & $\begin{array}{l}\text { OPANA ER TAB } \\
30 \mathrm{MG}\end{array}$ & $\begin{array}{l}\text { Oxymorphone } \mathrm{HCl} \\
\text { Tab SR 12HR } 30 \\
\text { MG (Crush } \\
\text { Resistant) }\end{array}$ & 0 & 3 & 3 & 30 & 90 \\
\hline
\end{tabular}


Table 2. (continued)

\begin{tabular}{|c|c|c|c|c|c|c|c|}
\hline $\begin{array}{l}\text { gpi_cd } \\
\text {. }\end{array}$ & drug_nm & gpi_nm & short_act & max_daily & morph_eqv_fctr & drg_strnth_mg & $\overline{\text { adj_dose }}$ \\
\hline 65100080107440 & $\begin{array}{l}\text { OPANA ER TAB } \\
40 \mathrm{MG}\end{array}$ & $\begin{array}{l}\text { Oxymorphone } \mathrm{HCl} \\
\text { Tab SR 12HR } 40 \\
\text { MG }\end{array}$ & 0 & 6 & 3 & 40 & 120 \\
\hline 65100080107485 & $\begin{array}{l}\text { OPANA ER TAB } \\
40 \mathrm{MG}\end{array}$ & $\begin{array}{l}\text { Oxymorphone } \mathrm{HCl} \\
\text { Tab SR 12HR } 40 \\
\text { MG (Crush } \\
\text { Resistant) }\end{array}$ & 0 & 6 & 3 & 40 & 120 \\
\hline 65100080107405 & $\begin{array}{l}\text { OPANA ER TAB } \\
5 \mathrm{MG}\end{array}$ & $\begin{array}{l}\text { Oxymorphone } \mathrm{HCl} \\
\text { Tab SR 12HR } 5 \\
\text { MG }\end{array}$ & 0 & 3 & 3 & 5 & 15 \\
\hline 65100080107455 & $\begin{array}{l}\text { OPANA ER TAB } \\
5 \mathrm{MG}\end{array}$ & $\begin{array}{l}\text { Oxymorphone } \mathrm{HCl} \\
\text { Tab SR 12HR } 5 \\
\text { MG (Crush } \\
\text { Resistant) }\end{array}$ & 0 & 3 & 3 & 5 & 15 \\
\hline 65100080107407 & $\begin{array}{l}\text { OXYMORPHONE } \\
\text { TAB 7.5MG ER }\end{array}$ & $\begin{array}{l}\text { Oxymorphone } \mathrm{HCl} \\
\text { Tab SR 12HR } 7.5 \\
\text { MG }\end{array}$ & 0 & 3 & 3 & 7.5 & 22.5 \\
\hline 65100091100340 & $\begin{array}{l}\text { NUCYNTA TAB } \\
\text { 100MG }\end{array}$ & $\begin{array}{l}\text { Tapentadol HCl Tab } \\
100 \mathrm{MG}\end{array}$ & 1 & 6 & 0.4 & 100 & 40 \\
\hline 65100091100320 & $\begin{array}{l}\text { NUCYNTA TAB } \\
50 \mathrm{MG}\end{array}$ & $\begin{array}{l}\text { Tapentadol HCl Tab } \\
50 \mathrm{MG}\end{array}$ & 1 & 12 & 0.4 & 50 & 20 \\
\hline 65100091100330 & $\begin{array}{l}\text { NUCYNTA TAB } \\
75 \mathrm{MG}\end{array}$ & $\begin{array}{l}\text { Tapentadol HCl Tab } \\
75 \mathrm{MG}\end{array}$ & 1 & 8 & 0.4 & 75 & 30 \\
\hline 65100091107430 & $\begin{array}{l}\text { NUCYNTA ER TAB } \\
100 \mathrm{MG}\end{array}$ & $\begin{array}{l}\text { Tapentadol HCl Tab } \\
\text { SR 12HR } 100 \mathrm{MG}\end{array}$ & 0 & 3 & 0.4 & 100 & 40 \\
\hline 65100091107440 & $\begin{array}{l}\text { NUCYNTA ER TAB } \\
\text { 150MG }\end{array}$ & $\begin{array}{l}\text { Tapentadol HCl Tab } \\
\text { SR 12HR } 150 \mathrm{MG}\end{array}$ & 0 & 3 & 0.4 & 150 & 60 \\
\hline 65100091107450 & $\begin{array}{l}\text { NUCYNTA ER TAB } \\
200 \mathrm{MG}\end{array}$ & $\begin{array}{l}\text { Tapentadol HCl Tab } \\
\text { SR 12HR } 200 \mathrm{MG}\end{array}$ & 0 & 2 & 0.4 & 200 & 80 \\
\hline 65100091107460 & $\begin{array}{l}\text { NUCYNTA ER TAB } \\
250 \mathrm{MG}\end{array}$ & $\begin{array}{l}\text { Tapentadol HCl Tab } \\
\text { SR 12HR } 250 \mathrm{MG}\end{array}$ & 0 & 2 & 0.4 & 250 & 100 \\
\hline 65100091107420 & $\begin{array}{l}\text { NUCYNTA ER TAB } \\
50 \mathrm{MG}\end{array}$ & $\begin{array}{l}\text { Tapentadol HCl Tab } \\
\text { SR } 12 \mathrm{HR} 50 \mathrm{MG}\end{array}$ & 0 & 3 & 0.4 & 50 & 20 \\
\hline
\end{tabular}

APPENDIX 3: RESULTS FOR THE FINAL MODEL

Table 3 Type III Sums of Squares Table

\begin{tabular}{|c|c|c|c|}
\hline Source & DF & Chi-square & $\operatorname{Pr}>$ ChiSq \\
\hline Opioid analgesic dose & 4 & 120.88 & $<0.0001$ \\
\hline Interval & 1 & 2.14 & 0.1439 \\
\hline Age & 1 & 38.26 & $<0.0001$ \\
\hline Gender & 1 & 8.15 & 0.0043 \\
\hline U.S. region & 3 & 1.83 & 0.6076 \\
\hline Back pain & 1 & 0.16 & 0.6897 \\
\hline Large joint arthritis, other musculoskeletal & 1 & 5.15 & 0.0233 \\
\hline Neuropathy & 1 & 1.11 & 0.2921 \\
\hline Chronic pain (unspecified) & 1 & 39.03 & $<0.0001$ \\
\hline Headache & 1 & 0.11 & 0.7406 \\
\hline Depression & 1 & 102.29 & $<0.0001$ \\
\hline Anxiety or PTSD & 1 & 0.06 & 0.8135 \\
\hline Psychosis & 1 & 66.59 & $<0.0001$ \\
\hline Alcohol abuse & 1 & 152.28 & $<0.0001$ \\
\hline Other substance abuse & 1 & 122.12 & $<0.0001$ \\
\hline Antidepressant therapy & 3 & 11.77 & 0.0082 \\
\hline Benzodiazepine therapy & 3 & 127.39 & $<0.0001$ \\
\hline Zolpidem therapy & 3 & 11.2 & 0.0107 \\
\hline Opioid $\times$ Depression & 4 & 36.53 & $<0.0001$ \\
\hline Antidepressant therapy $\times$ Depression & 3 & 20.2 & 0.0002 \\
\hline Benzodiazepine therapy $\times$ Anxiety or PTSD & 3 & 10.36 & 0.0157 \\
\hline Zolpidem therapy $\times$ Anxiety or PTSD & 3 & 8.79 & 0.0300 \\
\hline
\end{tabular}




\section{APPENDIX 3: RESULTS FOR THE FINAL MODEL (CONT.)}

Table 4 Adjusted Odds Ratios for Drug Overdose Associated with Significant Interactions of Opioid Analgesics and Selected Psychotherapeutic Drugs with Mental Health Conditions

\begin{tabular}{|c|c|c|}
\hline \multirow[b]{2}{*}{ Opioid analgesic dose (average daily dose per 6-month interval) } & \multicolumn{2}{|c|}{ Adjusted odds ratio $(95 \% \mathrm{CI})^{*}$} \\
\hline & Depression $=$ no & Depression $=$ yes \\
\hline $0 \mathrm{mg}$ & 1 & $3.96(3.00,5.24)$ \\
\hline $1-19 \mathrm{mg}$ & $0.80(0.50,1.27)$ & $4.75(3.24,6.97)$ \\
\hline $20-49 \mathrm{mg}$ & $1.54(1.23,1.94)$ & $5.47(4.23,7.09)$ \\
\hline $50-99 \mathrm{mg}$ & $2.08(1.61,2.69)$ & $6.44(4.85,8.54)$ \\
\hline$\geq 100 \mathrm{mg}$ & $4.34(3.37,5.57)$ & $7.06(5.30,9.42)$ \\
\hline Antidepressant therapy (days per 6-month interval) & Depression $=$ no & Depression $=$ yes \\
\hline None & 1 & $5.25(4.25,6.48)$ \\
\hline $1-30$ day & $1.98(1.48,2.65)$ & $5.51(4.14,7.34)$ \\
\hline $31-90$ day & $1.59(1.18,2.15)$ & $4.39(3.39,5.68)$ \\
\hline $91-180$ day & $1.33(1.05,1.68)$ & $4.15(3.36,5.12)$ \\
\hline Benzodiazepine therapy (days per 6-month interval) & Anxiety/PTSD $=$ no & Anxiety/PTSD=yes \\
\hline None & 1 & $1.29(0.99,1.70)$ \\
\hline $1-30$ day & $1.79(1.41,2.26)$ & $2.20(1.62,3.00)$ \\
\hline $31-90$ day & $2.62(2.06,3.34)$ & $2.03(1.49,2.78)$ \\
\hline $91-180$ day & $2.85(2.34,3.48)$ & $2.56(1.97,3.32)$ \\
\hline Zolpidem therapy (days per 6-month interval) & Anxiety/PTSD $=$ no & Anxiety/PTSD $=$ yes \\
\hline None & 1 & $1.14(0.97,1.35)$ \\
\hline $1-30$ & $1.67(1.21,2.3)$ & $1.14(0.76,1.72)$ \\
\hline $31-90$ & $1.06(0.71,1.57)$ & $1.77(1.25,2.51)$ \\
\hline $91-180$ & $1.54(1.2,1.99)$ & $1.30(0.96,1.77)$ \\
\hline
\end{tabular}

* Other variables in the model include: opioid daily MED category, time interval, age, gender, region, five chronic non-cancer pain conditions, anxiety/ PTSD, depression, psychotic disorder, alcohol abuse, drug abuse, antidepressant therapy, benzodiazepine therapy and zolpidem per 6-month interval (four levels: none, 1-30 days, 31-90 days, 91-180 days)

\section{APPENDIX 4: COMBINATION DRUGS FILLED BY PERSONS WITH DEPRESSION OR ANXIETY/PTSD BY 6-MONTH INTERVAL}

Table 5 Combination Drugs Filled by Persons with Depression or Anxiety/PTSD by 6-Month Interval

\begin{tabular}{|c|c|c|c|c|c|c|c|c|}
\hline Characteristic & 1 & 2 & 3 & 4 & 5 & 6 & 7 & Total \\
\hline All subjects, $\mathbf{N}$ & 206,869 & 162,706 & 118,660 & 80,602 & 53,562 & 30,801 & 5080 & 658,280 \\
\hline Subjects with depression, N (\%) & $\begin{array}{l}14,088 \\
(6.8)\end{array}$ & $\begin{array}{l}15,456 \\
(9.5)\end{array}$ & $\begin{array}{l}13,813 \\
(11.6)\end{array}$ & $\begin{array}{l}10,657 \\
(13.2)\end{array}$ & $\begin{array}{l}7941 \\
(14.8)\end{array}$ & $\begin{array}{l}5331 \\
(17.3)\end{array}$ & $\begin{array}{l}1182 \\
(23.3)\end{array}$ & $\begin{array}{l}68,468 \\
(10.4)\end{array}$ \\
\hline Opioids+Antidepressants, N (\%) & $\begin{array}{l}9667 \\
(68.6)\end{array}$ & $\begin{array}{l}6276 \\
(40.6)\end{array}$ & $\begin{array}{l}5027 \\
(36.4)\end{array}$ & $\begin{array}{l}3576 \\
(33.6)\end{array}$ & $\begin{array}{l}2538 \\
(32)\end{array}$ & $\begin{array}{l}1750 \\
(32.8)\end{array}$ & $\begin{array}{l}482 \\
(40.8)\end{array}$ & $\begin{array}{l}29,316 \\
(42.8)\end{array}$ \\
\hline Opioids+Benzodiazepines, $\mathrm{N}(\%)^{*}$ & $\begin{array}{l}6329 \\
(44.9)\end{array}$ & $\begin{array}{l}4547 \\
(29.4)\end{array}$ & $\begin{array}{l}3733 \\
(27)\end{array}$ & $\begin{array}{l}2711 \\
(25.4)\end{array}$ & $\begin{array}{l}1995 \\
(25.1)\end{array}$ & $\begin{array}{l}1416 \\
(26.6)\end{array}$ & $\begin{array}{l}431 \\
(36.5)\end{array}$ & $\begin{array}{l}21,162 \\
(30.9)\end{array}$ \\
\hline Opioids + zolpidem, N (\%) ${ }^{*}$ & $\begin{array}{l}2818 \\
(20.0)\end{array}$ & $\begin{array}{l}2010 \\
(13.0)\end{array}$ & $\begin{array}{l}1659 \\
(12.0)\end{array}$ & $\begin{array}{l}1248 \\
(11.7)\end{array}$ & $\begin{array}{l}896 \\
(11.3)\end{array}$ & $\begin{array}{l}645 \\
(12.1)\end{array}$ & $\begin{array}{l}189 \\
(16.0)\end{array}$ & $\begin{array}{l}9465 \\
(13.8)\end{array}$ \\
\hline $\begin{array}{l}\text { Opioids }+ \text { Antidepressants }+ \\
\text { Benzodiazepines, N }(\%)^{*}\end{array}$ & $\begin{array}{l}4856 \\
(34.5)\end{array}$ & $\begin{array}{l}3319 \\
(21.5)\end{array}$ & $\begin{array}{l}2640 \\
(19.1)\end{array}$ & $\begin{array}{l}1899 \\
(17.8)\end{array}$ & $\begin{array}{l}1368 \\
(17.2)\end{array}$ & $\begin{array}{l}940 \\
(17.6)\end{array}$ & $\begin{array}{l}286 \\
(24.2)\end{array}$ & $\begin{array}{l}15,308 \\
(22.4)\end{array}$ \\
\hline $\begin{array}{l}\text { Opioids+Benzodiazepines+ } \\
\text { Zolpidem, N (\%) }\end{array}$ & $\begin{array}{l}1677 \\
(11.9)\end{array}$ & $\begin{array}{l}1232 \\
(8.0)\end{array}$ & $\begin{array}{l}1007 \\
(7.3)\end{array}$ & $\begin{array}{l}749 \\
(7.0)\end{array}$ & $\begin{array}{l}515 \\
(6.5)\end{array}$ & $\begin{array}{l}370 \\
(6.9)\end{array}$ & $\begin{array}{l}108 \\
(9.1)\end{array}$ & $\begin{array}{l}5658 \\
(8.3)\end{array}$ \\
\hline $\begin{array}{l}\text { Opioids +Antidepressants+ } \\
\text { Benzodiazepines+ } \\
\text { Zolpidem, N (\%) }{ }^{*}\end{array}$ & $\begin{array}{l}1368 \\
(9.7)\end{array}$ & $\begin{array}{l}956 \\
(6.2)\end{array}$ & $\begin{array}{l}782 \\
(5.7)\end{array}$ & $\begin{array}{l}591 \\
(5.6)\end{array}$ & $\begin{array}{l}374 \\
(4.7)\end{array}$ & $\begin{array}{l}266 \\
(5.0)\end{array}$ & $\begin{array}{l}79 \\
(6.7)\end{array}$ & $\begin{array}{l}4416 \\
(6.5)\end{array}$ \\
\hline $\begin{array}{l}\text { Subjects with anxiety/ } \\
\text { PTSD, N (\%) }\end{array}$ & $\begin{array}{l}15,532 \\
(7.5)\end{array}$ & $\begin{array}{l}17,764 \\
(10.9)\end{array}$ & $\begin{array}{l}16,274 \\
(13.7)\end{array}$ & $\begin{array}{l}12,933 \\
(16.1)\end{array}$ & $\begin{array}{l}9626 \\
(18)\end{array}$ & $\begin{array}{l}6317 \\
(20.5)\end{array}$ & $\begin{array}{l}1346 \\
(26.5)\end{array}$ & $\begin{array}{l}79,792 \\
(12.1)\end{array}$ \\
\hline
\end{tabular}


Table 5. (continued)

\begin{tabular}{|c|c|c|c|c|c|c|c|c|}
\hline Characteristic & 1 & 2 & 3 & 4 & 5 & 6 & 7 & Total \\
\hline All subjects, $\mathbf{N}$ & 206,869 & 162,706 & 118,660 & 80,602 & 53,562 & 30,801 & 5080 & 658,280 \\
\hline Opioids+Antidepressants, $\mathrm{N}(\%)^{\dagger}$ & $\begin{array}{l}7766 \\
(50)\end{array}$ & $\begin{array}{l}5204 \\
(29.3)\end{array}$ & $\begin{array}{l}4298 \\
(26.4)\end{array}$ & $\begin{array}{l}3127 \\
(24.2)\end{array}$ & $\begin{array}{l}2265 \\
(23.5)\end{array}$ & $\begin{array}{l}1542 \\
(24.4)\end{array}$ & $\begin{array}{l}431 \\
(32)\end{array}$ & $\begin{array}{l}24,633 \\
(30.9)\end{array}$ \\
\hline Opioids+Benzodiazepines, $\mathrm{N}(\%)^{\dagger}$ & $\begin{array}{l}8715 \\
(56.1)\end{array}$ & $\begin{array}{l}5970 \\
(33.6)\end{array}$ & $\begin{array}{l}5007 \\
(30.8)\end{array}$ & $\begin{array}{l}3671 \\
(28.4)\end{array}$ & $\begin{array}{l}2663 \\
(27.7)\end{array}$ & $\begin{array}{l}1810 \\
(28.7)\end{array}$ & $\begin{array}{l}530 \\
(39.4)\end{array}$ & $\begin{array}{l}28,366 \\
(35.6)\end{array}$ \\
\hline Opioids + Zolpidem, N (\%) & $\begin{array}{l}2770 \\
(17.8)\end{array}$ & $\begin{array}{l}1976 \\
(11.1)\end{array}$ & $\begin{array}{l}1708 \\
(10.5)\end{array}$ & $\begin{array}{l}1306 \\
(10.1)\end{array}$ & $\begin{array}{l}939 \\
(9.8)\end{array}$ & $\begin{array}{l}646 \\
(10.2)\end{array}$ & $\begin{array}{l}179 \\
(13.3)\end{array}$ & $\begin{array}{l}9524 \\
(11.9)\end{array}$ \\
\hline $\begin{array}{l}\text { Opioids +Antidepressants } \\
\quad+\text { Benzodiazepines, N }(\%)^{\dagger}\end{array}$ & $\begin{array}{l}4922 \\
(31.7)\end{array}$ & $\begin{array}{l}3295 \\
(18.6)\end{array}$ & $\begin{array}{l}2685 \\
(16.5)\end{array}$ & $\begin{array}{l}1947 \\
(15.1)\end{array}$ & $\begin{array}{l}1414 \\
(14.7)\end{array}$ & $\begin{array}{l}952 \\
(15.1)\end{array}$ & $\begin{array}{l}289 \\
(21.5)\end{array}$ & $\begin{array}{l}15,504 \\
(19.4)\end{array}$ \\
\hline $\begin{array}{c}\text { Opioids +Antidepressants+ } \\
\text { Benzodiazepines, N }(\%)^{\dagger}\end{array}$ & $\begin{array}{l}4922 \\
(31.7)\end{array}$ & $\begin{array}{l}3295 \\
(18.6)\end{array}$ & $\begin{array}{l}2685 \\
(16.5)\end{array}$ & $\begin{array}{l}1947 \\
(15.1)\end{array}$ & $\begin{array}{l}1414 \\
(14.7)\end{array}$ & $\begin{array}{l}952 \\
(15.1)\end{array}$ & $\begin{array}{l}289 \\
(21.5)\end{array}$ & $\begin{array}{l}15,504 \\
(19.4)\end{array}$ \\
\hline $\begin{array}{l}\text { Opioids +Benzodiazepines }+ \\
\text { Zolpidem, N (\%) }\end{array}$ & $\begin{array}{l}1938 \\
(12.5)\end{array}$ & $\begin{array}{l}1390 \\
(7.8)\end{array}$ & $\begin{array}{l}1161 \\
(7.1)\end{array}$ & $\begin{array}{l}859 \\
(6.6)\end{array}$ & $\begin{array}{l}602 \\
(6.3)\end{array}$ & $\begin{array}{l}419 \\
(6.6)\end{array}$ & $\begin{array}{l}116 \\
(8.6)\end{array}$ & $\begin{array}{l}6485 \\
(8.1)\end{array}$ \\
\hline $\begin{array}{l}\text { Opioids + Antidepressants+ } \\
\text { Benzodiazepines } \\
+ \text { Zolpidem, N }(\%)^{\dagger}\end{array}$ & $\begin{array}{l}1270 \\
(8.2)\end{array}$ & $\begin{array}{l}877 \\
(4.9)\end{array}$ & $\begin{array}{l}732 \\
(4.5)\end{array}$ & $\begin{array}{l}572 \\
(4.4)\end{array}$ & $\begin{array}{l}357 \\
(3.7)\end{array}$ & $\begin{array}{l}252 \\
(4)\end{array}$ & $\begin{array}{l}70 \\
(5.2)\end{array}$ & $\begin{array}{l}4130 \\
(5.2)\end{array}$ \\
\hline
\end{tabular}

${ }^{*}$ Entries are $N(\%)$ among subjects with depression

${ }^{\dagger}$ Entries are $N(\%)$ among subjects with anxiety/PTSD 